\title{
HEINONLINE
}

Citation: 46 Vand. L. Rev. 5031993

Content downloaded/printed from

HeinOnline (http://heinonline.org)

Tue Jul 31 13:18:21 2012

-- Your use of this HeinOnline PDF indicates your acceptance of HeinOnline's Terms and Conditions of the license agreement available at http://heinonline.org/HOL/License

-- The search text of this PDF is generated from uncorrected OCR text.

-- To obtain permission to use this article beyond the scope of your HeinOnline license, please use:

https://www.copyright.com/ccc/basicSearch.do?

\&operation $=$ go\&search $\mathrm{Type}=0$

\&lastSearch $=$ simple\&all $=$ on\&titleOrStdNo $=0042-2533$

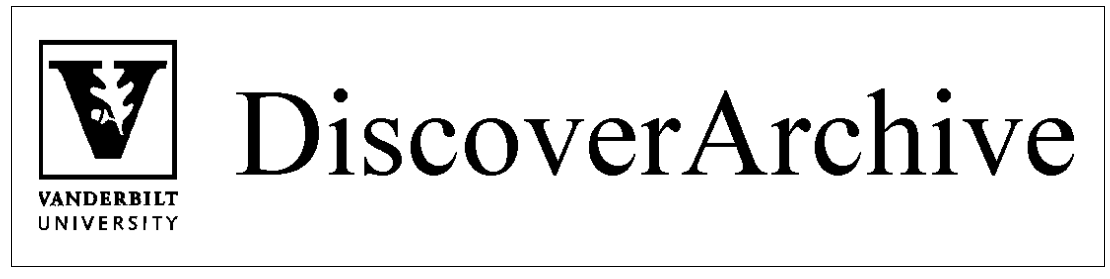

Retrieved from DiscoverArchive,

Vanderbilt University's Institutional Repository

This work was originally published in

46 Vand. L. Rev. 5031993 


\title{
VANDERBILT LAW REVIEW
}

\section{Judicial Review of Defensive} Tactics in Proxy Contests: When Is Using a Rights Plan Right?

\author{
Randall S. Thomas*
}

I. Introduction . . . . . . . . . . . . . . . . . . 504

II. Rights Plans: Defensive Tactics That Impact ShareHOLDER Voting Rights. . . . . . . . . . . . . . . 508

A. The Mechanics of Rights Plans ............. 510

B. The Impact of Rights Plans on Proxy Contests .. 512

C. Judicial Review of Incumbents' Use of Rights Plans ..............................

1. Paramount and Judicial Deference to Using Rights Plans Against Tender Offers ........

2. Judicial Review of Rights Plans' Application in Proxy Contests ................... a. Proxy Contests and Rights Plans: Moran v. Household International........

b. Apple Bancorp: Flip-In Pills in Joint Offers ...................... 520

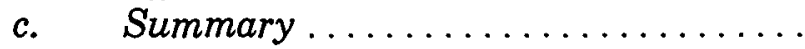

* Associate Professor of Law, University of Iowa; B.A. 1977, Haverford College; M.A. 1979, Ph.D. 1983, J.D. 1985, University of Michigan. The author gratefully acknowledges the helpful comments of Stephen M. Bainbridge, Bernard S. Black, Patricia Cain, Herhert J. Hovenkamp, Douglas Greene, Reinier Kraakman, Marcel Kahan, Williain Klein, Michael D. Green, Geoffrey P. Miller, Joel Seligman and David H. Vernon. The author would also like to acknowledge Andrea Carruthers, Jed Caven and Edward Poulsen for their assistance in researching this Article. 
A. Management's Interest in Protecting the Corporation and Its Shareholders ..................

B. The Importance of the Shareholder Franchise in the Market for Corporate Control.............

C. The Uncertain Case for Permitting Defensive Tactics in Proxy Contests .................... 1. Argument 1: Inferior Dissidents Win Proxy Contests Because of Information Imperfec-

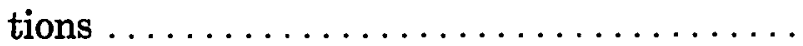

2. Argument 2: Self-Enriching Small Shareholders Win Proxy Contests...............

3. Argument 3: Proxy Contests Decrease Social

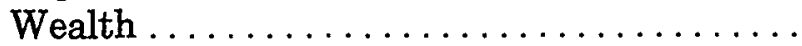

4. Argument 4: Joint Offers Pose the Same Threats as Tender Offers ..............

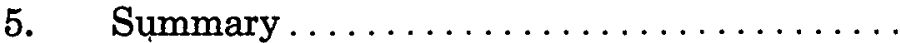

544

548

IV. When Is a Rights Plan Right in a Proxy Contest?..

A. What Threats Justify Deploying Rights Plans in Proxy Contests? ........................

B. Analyzing the Impact of Rights Plans on Dissident Election Campaigns: Common Sense and Statistics

C. Incumbents'Burden to Justify Using Rights Plans (and Other Defensive Tactics) in Proxy Contests .

V. ConcLusion

560

\section{INTRODUCTION}

Proxy contests ${ }^{1}$ have reemerged recently as an important part of the market for corporate control. ${ }^{2}$ After years of indifference to corpo-

1. This Article focuses on proxy contests for corporate control. In a proxy contest for corporate control, shareholders try to wrest control of a target corporation from the existing board of directors by winning a corporate election of directors. Issue contests, by comparison, are proxy contests over fundamental corporate changes, such as merger proposals or charter amendments, or proxy solicitations relating to shareholder proposals under Rule 14a-8. Lucian A. Bebchuk and Marcel Kahan, Proxy Contests, A Framework For Analyzing Legal Policy Towards Proxy Contests, 78 Cal. L. Rev. 1071, 1074-1075 (1990). This Article will use the term proxy contests to mean proxy contests for corporate control. It will use the term jomt offer to refer to a joint tender offer and proxy contest.

2. See id. at $\mathbf{1 0 7 5}$ (saying that "proxy contests have reemerged as an important tool for acquiring control" of corporations); Ronald J. Gilson, Lilli A. Gordon and John Pound, How the Proxy Rules Discourage Constructive Engagement: Regulatory Barriers to Electing a Minority of Directors, 17 J. Corp. L. 29, 31 (1991) (saying that "[t]here is a growing recognition that proxy contests are unportant"); Robert J. Klein, The Case For Heightened Scrutiny in Defense of the Shareholders' Franchise Right, 44 Stan. L. Rev. 129, 137 (1991) (saying that "[t]he market for corporate control in the post-poison pill era must ultimately rely on the shareholders' right to elect their agents"). See also John Pound, Proxy Contests and the Efficiency of Shareholder Oversight, 
rate elections, dissident shareholders have turned once again to the ballot box as a means of removing unwanted management. ${ }^{3}$ In a surprisingly large number of these battles, the challengers have succeeded in getting all or much of what they wanted. ${ }^{4}$

The resurgence of proxy contests has sparked renewed interest by incumbent managements in developing powerful new defensive tactics in corporate elections. ${ }^{5}$ Incumbents' time-honored campaign strategies, such as switching the annual shareholders' meeting date, or restricting the potential candidates who can run for office, are no longer sufficient to ensure a management victory. In their place incumbents have substituted more drastic measures, such as Rights Plans, ${ }^{6}$ popularly referred

20 J. Fin. Econ. 237 (1988); John Pound, Proxy Voting and the SEC: Democratic Ideals Versus Market Efficiency, 29 J. Fin. Econ. 241 (1991).

3. See Bebchuk and Kahan, $78 \mathrm{Cal}$. L. Rev, at 1073-74. After a rapid rise in the number of proxy contests in the late 1980 s and early 1990 s, the number of proxy contests declined modestly in 1992. Proxy Season Ends Quietly, Institutional Investor, Inc. 6 (June 15, 1992).

4. Georgeson \& Company, Inc., Proxy Contest Study, October 1984 to September 1990 (Dec. $14,1990)$. This report found that while incumbents experienced total victory in over $40 \%$ of the proxy contests for corporate control, compared to challengers' $28 \%$ complete victory percentage, dissidents obtained some benefit from their proxy solicitation in a majority of these contests. Id. at 1. In fact, "[i]f we consider contests in which challengers won the vote, together with negotiated settlements during or after the contest and other developments within one year, challengers achieved significant advances toward their objectives or gained other benefits for themselves and other shareholders in $74 \%$ of all control contests." Id. at 5.

5. For example, Time, Inc.'s management devised a powerful antitakeover measure directed toward the use of the proxy fight: if dissidents replaced five of the 27 member Time board of directors, then the equity of the common shareholders would be diluted significantly. Gilson, Gordon, and Pound, 17 J. Corp. L. at 29 (cited in note 2). A second example of these powerful new defensive tactics is the new Pennsylvania antitakeover statute. At the request of management interests, the drafters designed the statute to discourage explicitly proxy contests and to forbid the use of discretionary proxies by dissident shareholder groups. $15 \mathrm{~Pa}$. Cons. Stat. Ann. $\S 275$ (Purdon 1991); Stephen M. Bainbridge, Redirecting State Takeover Laws At Proxy Contests, 1992 Wis. L. Rev. 1071, 1093-95.

6. Rights Plans generally take the following form: The corporation distributes to its common shareholders a dividend in the form of a new class of convertible preferred stock. The board of directors determines the terms of the stock pursuant to a "blank check" provision in the certificate of incorporation that permits the board to authorize this class of stock with unstated terms that the board would fill in at the time of the stock's issuance. This new stock, or right, becomes convertible into valuable securities if a hostile acquirer takes certain actions. The Rights Plan threatens massive financial penalties to the acquirer if it proceeds with a hostile acquisition.

Rights Plans are one of the most powerful antitakeover defenses available to a target company. They were developed originally to deter two-tiered, front-end-loaded tender offers that coerced shareholders into tendering into the offer for fear of receiving a poor price for their shares in the back end of the transaction. Moran v. Household International, Inc., 500 A.2d 1346, 1356 (Del. 1985). Subsequently, their use has spread to precluding shareholders from accepting all-cash, allshares, premium-priced tender offers. See Part II.B. for further discussion of Rights Plans and their impact on proxy contests. 
to as "poison pills," that sharply limit, or even ehminate, shareholders' ability to elect the directors of their choice."

Should judges permit incumbents to use these powerful defensive tactics to thwart dissident shareholders' efforts to unseat existing managers? This Article argues that the courts have mistakenly favored incumbents in resolving conflicts between incumbents' desire to use defensive tactics to protect themselves and target company shareholders from "harmful" proxy contests, and the shareholders' need to have an effective mechanism for replacing unwanted (and inefficient) managers.

This is particularly clear in the lenient judicial review of the use of Rights Plans, a critical defensive tactic, in proxy contests. Rights Plans are especially important defensive tactics because they can be implemented quickly by a target company's board of directors without shareholder approval, may completely preclude stockholders from accepting a tender offer, and, if triggered, impose no direct cost on other shareholders. ${ }^{8}$ If a board of directors can use a Rights Plans to eliminate effectively shareholders' ability to remove incumbents through the election process, then shareholders will have lost control of their corporation.

The arguments made in favor of using Rights Plans (and other defensive tactics) in proxy contests are weak. Several of them rest on invalid assumptions about shareholder apathy and lack of information. ${ }^{9}$ Others mistakenly claim that proxy contests are not an important method of disciplining corporate management. ${ }^{10}$ Further, these argu-

7. Other important new defensive tactics include the sale of large blocks of stock to friendly third parties and to employees through an employee stock option plan ("ESOP"), see Shamrock Holdings, Inc. v. Polaroid Corp., 559 A.2d 257 (Del. 1989), and new powerful state antitakeover statutes tbat prohibit the voting of discretionary proxies cast for dissidents. See Committee for New Management of Guaranty Bancshares Corp. v. Dimeling, 772 F. Supp. 230 (E.D. Pa. 1991) (interpreting the new Pennsylvania antitakeover statute).

8. Jeffrey N. Gordon, Corporations, Markets, and Courts, 91 Colum. L. Rev. 1931, 1946 (1991). A variety of other less powerful defensive tactics exist, including classified boards of directors, changes of annual meeting dates, dual class stock recapitalizations, elimination of cumulative voting, advance notice of director nomination by-laws, and advance notice of business by-laws. For further discussion of these defensive tactics, see Irwin H. Warren and Kevin G. Abrams, Evolving Standards of Judicial Review of Procedural Defenses in Proxy Contests, 47 Bus. Law. 647 (1992); Bainbridge, 1992 Wis. L. Rev. at 1071 (cited in note 5).

9. See notes 133-65 and accompanying text for discussion of these arguments.

10. Corporate elections are an important method of disciplining inefficient or incompetent managers. Existing empirical research shows that positive stock price increases are associated with proxy contests. The costs of proxy contests appear to offset only partially these benefits. See notes 166-89 and accompanying text for further discussion.

Shareholder voice may also serve as a mechanism to eliminate unwanted antitakeover defenses, such as the Rights Plan. See Jeffrey N. Gordon, Shareholder Initiative: A Social Choice and Game Theoretic Approach, 60 U. Cin. L. Rev. 347, 347-48 (1991). For example, in 1990, 33 companies received shareholder-sponsored poison pill initiatives that called for the redemption of 
ments attach little weight to the shareholders' need to have a means of removing unwanted incumbents. ${ }^{11}$ In pragmatic terms, permitting the use of Rights Plans against proxy contests may virtually eliminate shareholders' ability to express their dissatisfaction effectively. ${ }^{\mathbf{1 2}}$

Given that the justifications for allowing the use of Rights Plans against dissident proxy campaigns are, at best, weak, what standard should judges apply to decide when their use is permissible? Under current law, judges examine the threats posed by a proxy contest to the corporation, and look at the reasonableness of the target company board's response to that threat, to decide whether they should permit incumbents' defensive tactics. The courts generally have deferred to management's decisions to employ Rights Plans.

Courts should revise the current judicial balancing tests for defensive tactics in proxy contests, such as Rights Plans, to better protect shareholder voting rights. Courts must severly limit the range of threats that management can claim are posed by a proxy contest to a company's shareholders. Judges should assess the reasonableness of incumbents' responses to these threats based on the defensive tactics' impact on a dissident's chances of winning a proxy contest. The law ought to prohibit certain features of Rights Plans that preclude successful proxy contests. With other less restrictive aspects of Rights Plans (and other defensive tactics), incumbents should have the burden of persuading the court that tangible benefits conferred upon shareholders justify the negative impacts of defensive tactics.

This Article begins by describing the structure of Rights Plans, their impact on proxy contests, and the courts' attempts to determine when and how incumbents can use Rights Plans in a proxy contest. The next section analyzes the theoretical importance of the shareholder franchise and the arguments for allowing a board of directors to use defensive tactics in proxy contests. It critiques claims that the best in-

the poison pill or for submission of its use to a shareholder vote. See Klein, 44 Stan. L. Rev. at 134 (cited in note 2).

11. The dechine of the tender offer, and the increased usage of "index" investing, sharply limit the ability of many shareholders, especially large institutional ones, to sell their shares. Gordon, 60 U. Cin. L. Rev. at 347-48 (cited in note 10). Large institutional shareholders frequently invest their funds in equity markets by purchasing a basket of stocks that reflect an underlying stock index, such as the Standard and Poor's 500 or the Dow Jones industrial index. These institutions then hold these shares over the long term to insure that the institution's financial performance matches that of the index and that their transaction costs are low.

12. Incumbents could safely ignore shareholder "voice" in corporate decisionmaking if they knew that their jobs at a corporation were protected completely. Without a credible threat that shareholders could subject intransigent management to removal if they did not improve their performance, inany of the benefits of institutional investors' monitoring of corporate managers undoubtedly would disappear. See notes 122-26 and accompanying text for further discussion of this point. 
terests of shareholders and society warrant the use of defensive tactics in proxy contests. The final section of the Article argues in favor of revising existing tests for evaluating incumhents' use of Rights Plans in proxy contests.

\section{Rights Plans: Defensive Tactics That Impact Shareholder Voting RIghts}

Proxy contests are not a new method of gaining control of a corporation. In the 1950 s and $1960 \mathrm{~s}$, proxy contests were the most effective way for shareholders to remove unwanted management. ${ }^{13}$

By the early 1970s, however, the tender offer had displaced the proxy contest as the preferred change of control mechanism. ${ }^{14}$ Tender offers were easier to win than proxy contests because shareholders were inore willing to sell their shares to unknown dissident shareholders than to agree to vote for them in an election. This was particularly true when management was painting the dissidents as self-interested raiders. For the next two decades, the proxy contest languished.

Recently, the attraction of the tender offer alone as a method of forcing out unwanted management has fallen dramatically. ${ }^{15}$ State legislatures and the courts have provided directors with access to a defen-

13. Edward R. Aranow and Herbert A. Einhorn, Proxy Contests For Corporate Control 3 (Columbia, 1968). Before the advent of the tender offer, the shareholders' only other alternative was to ask the directors to remove incumbent management, something that boards were reluctant to do. In recent years, outside directors have become more unilitant about removing incumbent chief executive officers of poorly performing companies at the request of large shareholders. See Elisabeth Holtzinan, When Management Falls Down On The Job, Pension Funds Can Put Independent Directors On The Board, Washington Post A17 (May 26, 1992). See also John Pound, After Takeovers, Quiet Diplomacy, Wall St. J. A10 (June 8, 1992).

14. Professor Loss summarized the reasons for the rise of the tender offer and the relative decline in the usage of proxy contests as follows: (1) Prior to 1968, when the Williams Act was enacted, no federal regulation of tender offers remotely comparable to the proxy rules existed (with the exceptions of several provisions of the Bank Holding Act and the Investment Company Act regulating the purchase of securities); (2) this lack of regulation allowed a hostile acquirer to catch management by surprise; (3) an acquirer could extend the offer for a limited period of time, preventing management from building up defenses and minunizing its cost; (4) the tender offer investment resulted in an investment as well as the purchase of control; and (5) if the tender offer was not successful, the bidder usually could dispose of its stake without a loss, or at a profit, to the target or a third-party acquirer of the target. Louis Loss, Fundamentals of Securities Regulation 498 (Little Brown, 2d ed. 1988). Another important reason why tender offers are preferable to proxy contests is that the corporate acquirer obtains most of the benefit of his or her efforts in refornining the corporation, whereas in a proxy contest other shareholders get to free-ride on the efforts of the dissident. Ronald J. Gilson and Bernard S. Black, The Law and Finance of Corporate Acquisitions 598 (Supp. 1992).

15. Warren and Abrams, 47 Bus. Law. at 647-48 (cited in note 8). Tight credit and the collapse of the junk bond market contributed to the decline of the tender offer and the increased popularity of the proxy contest. The junk bond market's difficulties have limited severely the ability of potential acquirers to finance tender offers at the above-market prices needed to succeed. The current economic recession and banking crisis have increased further the difficulty of raising 
sive arsenal, including the Rights Plan, capable of defeating a naked tender offer. ${ }^{16}$ The decline of the tender offer, and an increased level of activism by institutional stockholders, ${ }^{17}$ breathed new life into the proxy contest. ${ }^{18}$ In particular, the joint tender offer and proxy contest has become popular, ${ }^{19}$ especially when the Rights Plan of the target company does not include a "continuing director" provision, ${ }^{20}$ or when the pertinent state antitakeover statute permits the newly elected directors to exempt the dissident's proposed transaction from the Rights Plan's reach. ${ }^{21}$

With the increased popularity of proxy contests came renewed managerial attention to defenses against dissident electoral challenges.

sufficient financing for heavily leveraged acquisitions. Bainbridge, 1992 Wisc. L. Rev. at 1073 (cited in note 5).

16. The "just say no" defense, a combination of a Rights Plan and a tough state antitakeover statute, is lethal to most acquirers' atteunpts to appeal directly to the target's shareholders through a tender offer with the intent of gaining control of the counpany. This defense appears to have been judicially sanctioned in the Delaware courts' recent decisions about Rights Plans. See, for example, Paramount Communications, Inc. v. Time, Inc., 571 A.2d 1140 (Del. 1989). The United States Supreme Court's decisions upholding strong state antitakeover statutes appear to have approved those defenses as well. See CTS Corp. v. Dynamics Corporation of America, 481 U.S. 69 (1987). See also Gordon, 60 U. Cin. L. Rev. at 347 (cited in note 10).

17. The increased power and militancy of institutional shareholders on corporate governance issues has drawn scholarly attention to the possibility of true shareholder participation in the management and control of corporations. See generally Bernard S. Black, Agents Watching Agents: The Promise of Institutional Investor Voice, 39 U.C.L.A. L. Rev. 811 (1992); Bernard S. Black, The Value of Institutional Investor Monitoring: The Empirical Evidence, 39 U.C.L.A. L. Rev. 895 (1992); Bernard S. Black, Shareholder Passivity Reexamined, 89 Mich. L. Rev. 520 (1990); Edward B. Rock, The Logic and (Uncertain) Significance of Institutional Shareholder Activism, 79 Georgetown L. J. 445 (1991); John C. Coffee, Jr., Liquidity Versus Control: The Institutional Investor As Corporate Monitor, 91 Colum. L. Rev. 1277 (1991); Ronald J. Gilson and Reinier Kraakman, Reinventing the Outside Director: An Agenda for Institutional Investors, 43 Stan. L. Rev. 863 (1991); Jeffrey N. Gordon, Delegation and Initiative in Corporate Law: A Game Theoretic Approach to Problems of Shareholders and Managers, 60 U. Cin. L. Rev. 305 (1991).

18. Behchuk and Kahan, 78 Cal. L. Rev. at 1082 (cited in note 1). Proxy contests also have two inherent advantages over tender offers. First, proxy contests generally have lower transaction costs than hostile takeovers. Second, "the changes in property rights involved in hostile takeovers can distort shareholder choice of whether to sell shares to a raider" because of free-rider problems or pressures on shareholders to tender their shares when they might not otherwise choose to do so. Id. Antitakeover tactics also tend to be stronger for hostile takeovers than those currently permitted in proxy contests.

19. See Warren and Abrams, 47 Bus. Law. at 648-49 n.10 (cited in note 8), for a list of the most prominent joint offers of 1990 and 1991. These authors also note that disgruntled investors increasingly use the proxy mechanism in attempts to force corporations to sell, liquidate, or restructure themselves. Id. at 649 n.11.

20. If the Rights Plan contains a "continuing director" provision, then only persons who were directors prior to a specified event can vote to alter the Rights Plan. When no such provision is in the Rights Plan, the dissident shareholder's "initial objective may be to install directors who will rescind the plan or redeem the target company's shareholder rights." Id. at 650.

21. Id. 
Incumbents quickly realized the Rights Plan's value as a defensive tactic against dissident proxy campaigns.

\section{A. The Mechanics of Rights Plans}

Almost one-half of America's major public companies have Rights Plans, and the rest could put them in place quickly if desired. Most plans are authorized expressly by state corporate codes. ${ }^{22}$ While a variety of different plans have been dubbed Rights Plans, the Share Purchase Rights Plan is the most popular. ${ }^{23}$ To illustrate some of the common characteristics of this type of Rights Plan, tlie next footnote briefly summarizes the Apple Bancorp Rights Plan. ${ }^{24}$

A target company's board of directors usually creates a Rights Plan without a shareholder vote. The board authorizes tlie creation and distribution to its common stockholders of a dividend of one right for each sliare of common stock they own. The right entitles tlie sliareholder to purcliase common or preferred stock of the target company or any potential acquirer. Initially the rights are transferable only witl the stock and are not exercisable. However, once a "triggering event" occurs, sucl

22. In roughly one-half of the states, the corporate code expressly permits Rights Plans. Black, 89 Mich. L. Rev. at 550 n. 97 (cited in note 17). The courts in most other states have upheld poison pills. Id.

23. Martin Lipton and Erica Steinberger, 1 Takeovers and Freezeouts $\S 6.03[4][a]$ at 6-57

(1988). For a more detailed description of Rights Plans and the law surrounding them, see id.

24. The following summary of the terms of the Apple Bancorp Rights Plan is taken from 1 Moody's Bank and Finance Manual 1602 (1990):

APPLE BANCORP'S RIGHTS PLAN

Shareholders Rights Plan: In Nov., 1989 the Board of Directors adopted a Shareholder Rights Plan and declared a dividend of one preferred share purchase right ("Right") for each outstanding share of common stock of Bancorp. Each right will enable the holder thereof to buy a one-hundredth interest in a share of a new series of preferred stock of Bancorp at an exercise price of $\$ 1.35$. Initially, the rights will not be exerciseable and will transfer with and only with the shares of common stock. The rights will be exerciseable and separately transferable twenty business days after a person or group of persons acquires generally $15 \%$ or more of Bancorp's cominon stock, or twenty busiuess days, or such later date as may be determined by the Board of Directors, after a person or group announces a tender offer the consummation of which would result in ownership by a person or group of persons of generally $15 \%$ or more of the common stock.

If a person or group of persons becomes an Acquiring Person, otherwise than pursuant to a cash tender offer for all shares iu which such person or group increases its stake to $80 \%$ or more of the outstanding shares of common stock, each Right will entitle its holder (other than such person or members of such group) to purchase, at the then-current purcbase price of the Right, a number of shares of common stock of Apple Bancorp, Inc. having a market value twice the purchase price of the Right. Additionally, if Bancorp is acquired in a merger or other business combination transaction, each Right will entitle its holder to purchase, at the then-current purchase price of the Right, a number of shares of common stock of the acquiring company having a market value at that time of twice the purchase price of the Right. Subject to certain bimitations, Bancorp's Board of Directors may reduce the $15 \%$ threshold, but not to less than $10 \%$... 
as the acquisition of more than a specified percentage of the target company's stock, ${ }^{25}$ new rights certificates are distributed to the target company's stockholders and these certificates become exercisable. ${ }^{28}$

If the acquirer buys more than the specified percentage of stock, and then acquires the remaining target company stock in a merger, or other business combination transaction, the "flip-over"27 provisions of the Rights Plan allow the holders of the rights certificates, other than the acquirer, to buy the acquirer's common stock at a fifty percent discount. ${ }^{28}$ Most Rights Plans also have a "flip-in"29 provision that permits the holders of the rights certificates, except the acquirer, to purchase shares of the target company at half price if the acquirer purchases more than a certain percentage of the target company's stock. ${ }^{30}$ If either

25. The definition of a triggering event can vary between Rights Plans. One common definition is "the earlier of ten days after an entity acquires a certain percentage of the issuer's stock (typically $20 \%$ ) or commences a tender offer that would result in the acquiring person (the bidder) owning a certain percentage of the issuer's stock (typically 30\%)." Anthony Aughera, Shareholder Rights Plans: Saying No to Inadequate Tender Offers, 57 Fordham L. Rev. 803, 808 n.33 (1989).

26. The Apple Bancorp Rights Plan terms are reported in Moody's to be as follows: Initially, the rights will not be exerciseable and will transfer with and only with the shares of common stock. The rights will be exerciseable and separately transferable twenty business days after a person or group of persons acquires generally $15 \%$ or more of Bancorp's common stock, or twenty business days, or such later date as may be determined by the Board of Directors, after a person or group announces a tender offer the consummation of which would result in ownership by a person or group of persons of generally $15 \%$ or more of the common stock.

1 Moody's Bank and Finance Manual at 1602 (cited in note 24).

27. Lipton and Steinberger, 1 Takeovers and Freezeouts $\$ 6.03[4][\mathrm{a}]$ at 6-57 (cited in note 23). See also Augliera, 57 Fordham L. Rev. at 808-09 (cited in note 25). This adversely affects the acquiring companies' stockholders by diluting their equity interest in their company. Id.

Fhp-over provisions do not stop an acquirer from buying a controlling, but not $100 \%$, stake in a company because the flip-over provision does not kick in unless the acquirer attempts to engage in a business combination with the target company. Id.

28. The Apple Bancorp Rights Plan flip-over provisions provide that:

if Bancorp is acquired in a merger or otler business combination transaction, each Right will entitle its holder to purchase, at the then-current purchase price of the Right, a number of sliares of common stock of the acquiring company having a market value at that time of twice the purchase price of the Right.

1 Moody's Bank and Finance Manual at 1602.

29. Lipton and Steinberger, 1 Takeovers and Freezeouts $\& 6.03[4][a]$ at 6-57. The flip-in provision operates to increase substantially the shares the bidder must acquire and makes an acquisition far more expensive because it dilutes the investment and voting power of an acquiring entity. Aughiera, 57 Fordham L. Rev. at 808 (cited in note 25).

30. The Apple Bancorp Rights Plan flip-in provisions provide:

If a person or group of persons becomes an Acquiring Person, otherwise than pursuant to a cash tender offer for all shares in which such person or group increases its stake to $80 \%$ or more of the outstanding shares of common stock, each Right will entitle its holder (other than such person or members of such group) to purchase, at the then-current purchase price of tbe Right, a number of shares of common stock of Apple Bancorp, Inc. having a market value twice the purchase price of the Right.

1 Moody's Bank and Finance Manual at 1602. 
of the flip-in or flip-over provisions is triggered, the target company's shareholders will find that the rights are valuable and exercise them. The cost to the bidder of acquiring the target company is thus greatly increased, and the hostile takeover deterred.

The board of directors of the target company reserves the power to redeem, or buy back, the rights for a certain period of time at a nominal price. ${ }^{31}$ This gives the board tremendous negotiating leverage with the bidder: if the bidder agrees to the board's terms, the board can stop the rights from becoming redeemable, avert the economic devastation that would be inflicted on the bidder, and permit the bidder to acquire the target company. ${ }^{32}$ If the bidder does not agree to accept the board's demands, then the directors can, in many circumstances, use the Rights Plan to defeat the tender offer.

\section{B. The Impact of Rights Plans on Proxy Contests}

For a dissident shareholder group to win a proxy contest for corporate control, the shareholder group must either purchase enough voting shares to vote itself into office, or persuade enough other shareholders to vote for the dissident slate so that it obtains a majority of the votes cast in the election. An effective Rights Plan puts important obstacles in the way of both routes.

The Rights Plan's flip-in and flip-over features stop individual shareholders or shareholder groups from accumulating large amounts of the target company's stock. No potential acquirer or other shareholder will risk triggering a Rights Plan by accumulating more than the threshold level of shares because of the threat of massive discriminatory dilution. The trigger level therefore effectively sets a ceiling on the amount of stock that any shareholder can accumulate before launching a proxy contest.

The lower the threshold level, the greater the negative impact on a dissident group's ability to accumulate the company's stock. The most common trigger level for Rights Plans is twenty percent, but some plans go as low as ten percent. The current trend appears to be toward lowering the threshold level in newly created or amended Rights Plans. ${ }^{33}$

31. Augliera, 57 Fordham L. Rev. at 809 (cited in note 25). For example, the Apple Bancorp Rights Plan provides in part that "at any time prior to the date a person or group of persons becomes an Acquiring Person, a majority of the directors of Bancorp may vote to redeem the Rights for one cent per Right." 1 Moody's Bank and Finance Manual at 1602 (cited in note 24).

32. See Moran v. Household International, Inc., 490 A.2d 1059, 1066 (Del. Ch. 1985), aff'd, 500 A.2d 1346 (Del. 1985). See Part II.C.2.a. for further discussion of the Moran decisions.

33. See Black, 89 Mich. L. Rev. at 551 n.100 (cited in note 17). Some courts have shown hostility toward very low trigger levels, finding them to be excessive in relation to investors' need for protection. See, for example, Dynamics Corp. of America v. CTS Corp., 794 F.2d 250, 259 (7th Cir. 1986) (invalidating a Rights Plan with a $15 \%$ trigger level). 
Boards also can act rapidly to lower the threshold level if a large shareholder emerges. ${ }^{34}$ For imstance, if a dissident shareholder begins accumulating stock in preparation for a proxy contest, and files a Schedule 13D announcing that it has crossed the five percent level, the target company's board of directors could drop its Rights Plan's threshold from twenty percent to ten percent as quickly as it could call a directors' meeting to approve the change. ${ }^{35}$ Furthermore, many Rights Plans permit dropping the threshold limit retroactively if the target company's board of directors declares the dissident to be an "adverse person."ss

When dissident shareholder groups try to convince other shareholders to vote for thein, the Rights Plan throws up several obstacles. For example, in most Rights Plans, all shares held by a "beneficial owner" are counted toward the maximum number of shares that can be held without crossing the threshold level. A shareholder group is considered to be the beneficial owner of any stock that it has the right to vote, either directly or indirectly, except pursuant to revocable proxies given in response to public solicitations that the SEC has reviewed. ${ }^{37}$ This beneficial ownership definition precludes dissident shareholders from entering into agreements with other shareholders concerning the reimbursement of their proxy contest expenses or about the slate of candidates they intend to nominate for directors. ${ }^{38}$

Rights Plans also give the target companies' boards of directors considerable discretion to determine who among the shareholders should be considered members of a shareholder group. ${ }^{39}$ The uncertainty surrounding who the board will determine to be the members of a shareholder group, and how many shares the board will determine should be attributed to them, places a significant burden on dissident shareholder groups.

Rights Plans can create other, more direct impediments to shareholder proxy solicitations. Incumbent boards have used a Rights Plan to stop potential group members froin communicating with one an-

34. Black, 89 Mich. L. Rev. at 551 (cited in note 17).

35. See, for example, In re Chrysler Corporation Shareholders Litigation, No. 11873, 1992 Del. Ch. LEXIS 152 (July 27, 1992) (noting that the board reduced Rights Plan trigger level from $20 \%$ to $10 \%$ after potential bidder for company purchased $9.8 \%$ of the company's stock).

36. See Black, 89 Mich. L. Rev, at 551 n.101 (cited in note 17).

37. See id. at 551; Warren and Abrams, 47 Bus. Law. at 663 (cited in note 8). Beneficial ownership is defined using the Rule 13D definition. See id. at 663. This definition is drafted loosely enough to permit incumbents to interpret expansively its language to cover a wide variety of situations.

38. See In re Chrysler Corporation Shareholders Litigation, 1992 Del. Ch. LEXIS 152, at *9-17 (recognizing that Rights Plans deter collective action by shareholders in proxy contests).

39. See Black, 89 Mich. L. Rev, at $\mathbf{5 5 1 .}$ 
other. In one case, two large shareholders could not even discuss the possibility of launching a proxy contest under the terms of the target company's Rights Plan. ${ }^{40}$ In another case, the target company's poison pill retirement plan prevented shareholders from accepting more than $35 \%$ of the revocable proxies cast in an election. ${ }^{41}$ This would have stopped anyone from successfully waging a proxy contest.

The importance of a Rights Plan in a proxy contest is well-illustrated by the aborted 1991 proxy contest for Avon launched by Chartwell Associates and Argonaut Partners. In 1990, Chartwell, Argonaut, and some affiliated entities (the "Chartwell Group") launched a proxy contest to elect four directors, one-third of the classified board of Avon. The Chartwell Group settled this contest in exchange for two seats on the Avon board and the formation of a board committee to study ways of maximizing shareholder value. ${ }^{42}$

The Chartwell Group continued accumulating Avon shares. By 1991 it held $19.8 \%$ of Avon's total voting shares. ${ }^{43}$ Avon earlier had amended its Rights Plan to drop its threshold level to twenty percent, effectively stopping the Chartwell Group from accumulating more than that amount of stock without triggering the Rights Plan. ${ }^{44}$ With the 1991 Avon annual shareholders' meeting approaching, Argonaut Partners, which held three percent of Avon's stock, announced that it had withdrawn from the Chartwell Group. ${ }^{45}$ The remaining members of the Chartwell Group claimed that this reduced its percentage ownership of Avon stock ownership to $16.8 \%$, giving it room to purchase another $3.1 \%$ of Avon's stock before the 1991 annual meeting.

Avon promptly filed suit against Argonaut and the Chartwell Group claiming that the two remained members of the same share-

40. See Henley Group, Inc. v. Santa Fe Southern Pacific Corp., C.A. No. 9569 (Del. Ch. Mar. 11, 1988), in which the potential target of a proxy contest reduced the existing flip-in trigger of a Rights Plan from $50 \%$ to $20 \%$ to prevent two large shareholders who collectively owned $21 \%$ of the target company's stock from joining together in a proxy solicitation effort to remove management. Although the incumbent board subsequently amended the Rights Plan to allow the two shareholders to communicate with one another, the vice chancellor criticized the incumbents' use of the Rights Plan in this manner.

41. Sutton Holding Corp. v. Desoto, Inc., No. 12051, 1991 Del. Ch. LEXIS 85 (May 14, 1991) (invalidatimg this provision of a Rights Plan).

42. See Judi Perlman, Chartwell to Solicit Proxies to Gain Control Of Avon Board, Reuter Business Report (Jan. 31, 1991); William Taylor, Can Big Owners Make A Big Difference?, Harv. Bus. Rev. 70 (Sept./Oct. 1990).

43. See Chartwell Raises Avon Stake, Women's Wear Daily 15 (Aug. 9, 1990).

44. In an earlier amendment to its Rights Plan, Avon had attempted to lower the threshold level of its pill below the $20 \%$ level. Chartwell sued and the federal court enjoined this change as a violation of New York corporate law forbidding discrimination among shareholders holding less than $20 \%$ of a company's stock. Avon Products, Inc. v. Chartwell Associates, L.P., 738 F. Supp. 686 (S.D.N.Y. 1990), aff'd, 907 F.2d 322 (2d Cir. 1990).

45. Perlman, Reuter Business Report (cited in note 42). 
holder group under the terms of Avon's Rights Plan and that any further purchases of Avon stock by either one would trigger the Rights Plan. ${ }^{4}$ Shortly after Avon filed this litigation, Chartwell sold off all but $3.5 \%$ of its Avon stake. Before the 1991 annual meeting was held, the two sides settled the suit, with Avon the clear winner. ${ }^{47}$

The negative impact of Avon's Rights Plan on the Chartwell Group's proxy contest is apparent. The Chartwell Group could not purchase more than the Rights Plan's threshold level of Avon stock directly, nor could it act in unison with other shareholders to oust incumbent management if collectively the group's members would hold more than the threshold limit. Avon's ability to bring litigation claiming that, for the purposes of its Rights Plan, the Chartwell Group continued to exist, hurt the dissidents' efforts to attract new members or to purchase more stock themselves, although it did not stop them from receiving revocable proxies from other shareholders.

The impediments that Rights Plans create against effective dissident shareholder action in a proxy contest would not be so severe if the courts limited their scope. In fact, the courts have been slow to strike down any of the obstacles to shareholder action created by Rights Plans.

\section{Judicial Review of Incumbents' Use of Rights Plans}

\section{Paramount and Judicial Deference to Using Rights Plans Against Tender Offers}

Under Delaware law, directors have a fiduciary duty to protect the corporation from harm. This duty requires them to resist takeovers that they reasonably perceive are not in the corporation's and its shareholders' best interests. ${ }^{48}$ In the proper circumstances, the board of directors could satisfy these duties by keeping a Rights Plan in place, thereby precluding its shareholders from accepting an acquirer's tender offer. The board's exercise of its fiduciary duties in deciding to use a Rights Plan to stop a potential acquisition is subject to judicial review under a balancing test first announced in Unocal v. Mesa Petroleum. ${ }^{49}$

46. Chartwell Associates Files Counterclaim Against Avon, PR Newswire (Jan. 31, 1991).

47. Pierre Belec, Avon Says Chartwell Signs Truce, Ending Boardroom Battle, Reuter Business Report (Apr. 2, 1991). The terms of the settlement required Chartwell to sign a ten-year standstill agreement and drop its fight to obtain more board seats in the 1991 elections in exchange for payment of its legal fees and expenses and Avon's agreement to allow the two current Chartwell directors to remain on its board.

48. Unocal Corp. v. Mesa Petroleum Co., 493 A.2d 946, 954 (Del. 1985).

49. Id. at 954 . Although developed by the Delaware courts, many other states have followed the Unocal test. See, for example, Amanda Acquisition Corp. v. Universal Foods Corp., 708 F. Supp. 984, 1009 (E.D. Wisc. 1989) (applying Wisconsin law), aff'd on other grounds, 877 F.2d 496 
Unocal applies lieightened judicial review to the board's decision not to redeem a poison pill, or to use any other defensive tactic, because of the "omnipresent specter" that the directors might be acting in their own self-interest to preserve their jobs. ${ }^{\text {so }}$ The Unocal test is two pronged: first, the board must slow that it has reasonable grounds to believe that a threat to the corporation exists; and second, tlie directors must show that the defensive measure enacted is "reasonable" in relation to the threat posed by the attempted takeover. ${ }^{\mathrm{B1}}$ The Delaware Cliancery Court has applied this test to invalidate defensive tactics on several occasions. ${ }^{\text {.2 }}$ However, the Delaware Supreme Court's recent decision in Paramount Communications, Inc. $v$. Time, Inc. ${ }^{83}$ strongly suggests that wlien a corporation has a preexisting business plan, a target company's board of directors can use a Riglits Plan to bar its shareholders from accepting a lostile tender offer. ${ }^{54}$

The Delaware Supreme Court's Paramount decision expands in two directions the powers of a target company's board to reject a lostile tender offer: first, it enlarges the permissible range of threats that a board can point to in the first prong of the Unocal test; and second, it sharply cuts back on the scope of judicial review of the directors' assertion that a threat exists. ${ }^{55}$ Witl regard to the first point, prior chancery court case law had limited the threat that an all cash, all sliares tender offer posed to simple economic inadequacy. The cliancery court re-

(7th Cir. 1989); Gelco Corp. v. Coniston Partners, 652 F. Supp. 829, 845 (D. Minn. 1986) (applying Minnesota law), aff'd in part, vacated in part, $811 \mathrm{~F} .2 \mathrm{~d} 414$ (8th Cir. 1987). Recently, some states have adopted statutes that prohibit the application of the Unocal standard in reviewing actions by the boards of their domestic corporations. See, for example, Ind. Code Ann. § 23-1-35-1 (Burns 1992); 15 Pa. Cons. Stat. Ann. \& 1715 (Purdon 1991).

50. $493 \mathrm{~A} .2 \mathrm{~d}$ at 954 .

51. Id. at 955. For an in-depth analysis of the Unocal proportionality test, see Ronald J. Gilson and Reinier H. Kraakman, Delaware's Intermediate Standard for Defensive Tactics: Is There Substance to Proportionality Review?, 44 Bus. Law. 247 (1989). See also James F. Ritter, Unocal Corp. v. Mesa Petroleum Co., 72 Va. L. Rev. 851 (1986); Jan Jenson, Discrimination Against Shareholders in Opposing a Hostile Takeover, 59 S. Cal. L. Rev. 1319 (1986); Augliera, 57 Fordham L. Rev. at 803 (cited in note 25).

52. See, for example, Robert M. Bass Group, Inc. v. Evans, 552 A.2d 1227 (Del. Ch. 1988); AC Acquisitions Corp. v. Anderson, Clayton \& Co., 519 A.2d 103 (Del. Ch. 1986). In several cases, the Delaware Chancery Court ordered the redemption of a poison pill. See, for example, City Capital Associates v. Interco, Inc., 551 A.2d 787 (Del. Ch. 1988); Grand Metropolitan Public, Ltd. v. The Pillsbury Co., 558 A.2d 1049 (Del. Ch. 1988). In both Interco and Pillsbury, the chancery court found that it could define the threat to shareholder interests posed by an all cash, all shares hostile tender offer by answering the question of whether the shareholders would receive an adequate and fair price. Gordon, 91 Colum. L. Rev. at 1939 (cited in note 8).

53. 571 A.2d 1140 (Del. 1989).

54. Gordon, 91 Colum. L. Rev. at 1932, 1941, 1947. Gordon offers three alternative explanations of the Paramount decision: an economic analysis, a public choice analysis, and a socio-historical analysis. He argues that a socio-historical analysis of the dangers of unbridled takeover activity provides the most coherent explanation for the Delaware Supreme Court's decision.

55. Id. at 1941. 
stricted incumbents' response to this threat to a temporary deferral of shareholders' right to choose to accept a tender offer by, for example, allowing a Rights Plan to remain in place for a limited period of time. Paramount explicitly rejected this limitation and greatly expanded the list of potential threats that a board could consider under the first prong of Unocal. ${ }^{\text {sB }}$

Paramount also shifts the standard for judicial review of the directors' determination that a threat exists away from the independent judicial determination emphasized by prior chancery court decisions and toward a more lenient business judgment type standard. Indeed, when a board acts in good faith and after reasonable investigation, Paramount suggests there is "no place for the court's independent assessment of the board's assertion that a hostile bid presents a series of threats that warrant a preclusive response."57 This would seem to be true even when the defensive tactic applied, such as the Rights Plan, completely precludes the shareholders from choosing to accept a tender offer. ${ }^{58}$ In short, Paramount may mark the collapse of heightened judicial scrutiny for takeover defensive tactics against hostile tender offers and a retreat to their deferential review under the business judgment rule. ${ }^{58}$

56. Id. at 1942.

57. Id. at 1943. The Delaware Supreme Court, however, did condemn "management actions that are coercive in nature or force upon shareholders a management-sponsored alternative to a hostile offer." Paramount, 571 A.2d at 1154.

58. Gordon, 91 Colum. L. Rev. at 1937 n.21 (cited in note 8). The Chancery Court in Paramount carefully distinguished the poison pill, which it called a "control mechanism," from other defensive tactics that might have "independent business purposes," in deciding whether a target company board's response was proportionate to the threat posed by a tender offer. Id. at 1940. The Delaware Supreme Court drew no such distinction, apparently sanctioning the use of the poison pill as a proportionate response in a wide variety of circumstances. See id. at 1946.

59. Id. at 1945-47. In other words, the Delaware Supreme Court "seems to have abandoned the effort to subject defensive tactics in hostile takeovers to serious scrutiny, backing away from several recent precedents and undermining a sophisticated developing jurisprudence in the Chancery Court." Id. at 1947. 


\section{Judicial Review of Rights Plans' Application in Proxy Contests}

\section{a. Proxy Contests and Rights Plans: Moran v. Household International}

Judicial inquiry ${ }^{60}$ into the impact of a flip-over Rights Plan on insurgent's proxy contest efforts ${ }^{61}$ began in Moran $v$. Household International..$^{62}$ In that case, a substantial shareholder of the company who was not actively engaged in an effort to acquire the company challenged the validity of Household International's Rights Plan, one of the first Rights Plans put into place. The chancery court asked two questions: first, did the Rights Plan materially affect dissident shareholders' ability to win a proxy contest?; and second, if such an effect existed, was the application of the Riglits Plan justifiable as part of a policy of deterring liostile takeovers? In answering the first question, the cliancery court recognized that the Riglits Plan's prohibitions would stop dissident shareholders from accumulating blocks of the target company's stock. However, based on a very thin statistical record, ${ }^{6 s}$ the court

60. Prior to Moran, the courts used the test set out in Schnell v. Chris-Craft Industries, Inc., 285 A.2d 437 (Del. 1971), to determine the validity of defensive tactics in proxy contests. Schnell stopped management from impeding dissidents' efforts to wage a proxy contest when the incumbents acted "for the purpose of perpetuating [themselves] in office; and ... for the purpose of obstructing the legitimate efforts of dissident stockholders in the exercise of their rights to undertake a proxy contest against management." Id. at 439. Schnell requires a judicial finding that the incumbents' actions were taken "with a principal purpose of impeding the exercise of stockholder power through the vote." Stahl v. Apple Bancorp, Inc., 579 A.2d 1115, 1122 (Del. Ch. 1990) ("Apple Bancorp I').

The Delaware courts continue to apply Schnell to defensive "actions by directors that purposefully or otherwise result in the manipulation of the stockholders' voting rights ... [subjecting them] to strict judicial review." Warren and Abrams, 47 Bus. Law. at 652-53 (cited in note 8). Virtually every decision based on Schnell stems from board action being deliberately employed to frustrate or disenfrachise stockholders. Stroud $v$. Grace, 606 A.2d 75, 91 (Del. 1992). Altbough Schnell's apphication results in careful scrutiny of incumbents' defensive actions, to date no court has found that Schnell restricts incumbents' use of Rights Plans against proxy contests. Compare Davis Acquisition, Inc. v. NWA, Inc., C.A. No. 10761, 1989 WL 40845 (Del. Ch. Apr. 25, 1989) (raising the issue but decided on other grounds). After the Delaware Supreme Court's recent opinion in Stroud $v$. Grace, the Delaware courts will apply the Unocal test to determime the validity of using Rights Plans in proxy contests. $606 \mathrm{~A} .2 \mathrm{~d}$ at 92 n.3.

61. Moran involved a challenge to the validity of an early version of the Rights Plan, one which contained only a flip-over provision. Even this older version of the Rights Plan created a "proxy inhibition [that] arises because one of the events which trigger issuance of the [poison pill] preferred is the formation of a group representing $20 \%$ of Household stock for the purpose of conducting a proxy contest." Moran, 490 A.2d at 1079.

62. 490 A.2d 1059 (Del. Ch. 1985).

63. The court rehed exclusively on a report prepared by the defendants' proxy sohcitors and the testimony of one of the sohcitors in reaching this conclusion. Id. at 1079. For a discussion of why this evidence was inconclusive about the impact of Rights Plans on proxy contests, see Part IV.B. 
found the claim that a Rights Plan would impede a dissident shareholder's efforts to win a proxy contest to be "speculative."64

In the second part of the chancery court's analysis, it found that even if a Rights Plan negatively affected dissidents' efforts to win proxy contests, it was designed to stop two-tiered tender offers and easily could be circumvented and avoided if shareholders were allowed to purchase more than twenty percent of the target company's stock. ${ }^{65}$ When viewed as part of an overall policy adopted by the board to deter hostile tender offers, the Chancery Court held that the negative effects of the Rights Plan on a dissident's chances of winning a proxy contest did not invalidate the Rights Plan. ${ }^{66}$ The Delaware Supreme Court subsequently affirmed this decision. ${ }^{67}$

In short, Moran requires that a court look at the impact of a Rights Plan on a dissident's election campaign and at the Rights Plan's place in the company's program to defeat hostile tender offers. ${ }^{68}$ Given the weakness of the statistical evidence introduced in Moran, and the fact that Household International's Rights Plan lacked a flip-in trigger, the decision should not be viewed as having held conclusively that Rights Plans have an immaterial effect on proxy contests. ${ }^{69}$ Indeed, when the courts have found these effects to be very negative, they have invalidated the application of Rights Plans in proxy contests. ${ }^{70}$

64. Moran, 490 A.2d at 1080.

65. Id. For the Rights Plan to accomplish its purpose, the $20 \%$ threshold level must extend not only to individual loldings, but also to group holdings. See Stahl v. Apple Bancorp, Inc., C. A. No. 11510, 1990 Del. Cl. LEXIS 121 at *11 (Aug. 9, 1990) ("Apple Bancorp II")..

66. Moran, 490 A.2d at 1080.

67. Moran v. Household Int'l, Inc., 500 A.2d 1346 (Del. 1985). The Delaware Supreme Court concluded that the evidence introduced at trial supported the chancery court's finding that the Rights Plan would have a minimal effect on proxy contests. Id. It went on to reject the plaintiff's contention that Household's Riglits Plan would impermissibly burden sliarelıolders seeking to conduct a proxy contest. Id.

68. Althougl Moran was decided before the Unocal decision, a court easily could analyze it using Unocal's two part test. See Part II.C.2.c. for a discussion of the Apple Bancorp court's application of botli tests. The target company board could define the threat to the corporation, the first part of the Unocal test, as the threat of a lostile takeover. The board's response to this threat, installing a Riglits Plan that has a negative impact on a dissident shareholder's chances of winning a proxy contest, could be found to be reasonable if its effects on the sliareholder's cliances of winning a proxy contest were immaterial.

69. See notes 232-46 and accompanying text for discussion of this point.

70. In Sutton Holdings Corp. v. Desoto, Inc., the cliancellor determined that a poison retirement plan, whose dilution provisions were triggered by a dissident's receipt of proxies for more than $35 \%$ of the votes in an election of directors, precluded shareliolders from succeeding in a proxy contest. Sutton Holdings Corp. v. Desoto, Inc., No. 12051, 1991 Del. Ch. LEXIS 85 at *2-3 (May 14, 1991). The negative impact of the poison retirement plan on any dissident's chances of winning a proxy contest was clear: eliminating a dissident's ability to receive proxies destroys lier ability to win a proxy fight.

In anotlier case, Henley Group, Inc. v. Santa Fe Southern Pacific Corp., C.A. No. 9569, 1988 Del. Cl. LEXIS 32 at $* 29-39$ (April 18, 1988), the chancery court found that the application of a 


\section{b. Apple Bancorp: Flip-In Pills in Joint Offers}

While Moran showed how the courts would treat flip-over Rights Plans' application to proxy contests, the advent of the more potent flipin Riglits Plan provisions, ${ }^{71}$ and the rise of the joint offer ${ }^{72}$ raised the possibility that later courts might reevaluate Moran's conclusions about the impact of Rights Plans on proxy contests. Stahl v. Apple Bancorp, Inc. ${ }^{73}$ provided an opportunity for the chancery court to examine the impact of the flip-in Rights Plan on a dissident's chances of winning a joint offer.

Stanley Stahl, a thirty percent shareholder engaged in a joint offer for the control of Apple Bancorp, claimed that Apple Bancorp's Rights Plan's definition of beneficial ownerslip precluded him from forming revocable shareholder voting agreements with other shareholders when collectively they lield more than the threshold level of shares. ${ }^{74}$ The incumbent board agreed, but argued that these restrictions were necessary to preserve its bargaining position witl Stahl and to help it find a third-party bidder. ${ }^{75}$

The court's strong language about the need to protect the sharelolder franchise seemed to promise that it would carefully scrutinize Apple Bancorp's Rights Plan's restrictions. ${ }^{78}$ It found a strong "normative argument" against allowing "the side [controlling] the levers of power [to] employ tliem with respect to an election to coerce its opposition to restrict its legitimate electioneering activities."

Rights Plan had a negative impact on a dissident shareholder's proxy campaign. "The Court has found, as a preliminary factual matter, that the defendants' reduction of the Rights Plan triggering percentage to $20 \%$ did, at least initially, impair [the dissident's] ability to mount an effective proxy contest ..." Id. at *39 n.22 Only the board's subsequent decision to amend the Rights Plan to permit large stockholders to communicate with each other (after the board had reached an agreement with one of them) defeated the dissidents' efforts to have the change of the Rights Plan threshold trigger enjoined.

71. For a discussion of why flip-in provisions in Rights Plans are a stronger deterrent than flip-over provisions, see Lipton and Steinberger, 7 Takeovers and Freezeouts, \& 6.03[4][a] at 6-59 (cited in note 23).

72. See notes $13-21$ and accompanying text.

73. Apple Bancorp II 1990 Del. Ch. LEXIS 121.

74. The Apple Bancorp Rights Plan's definition of group was taken from Rule 13d-5 (17 CFR $\S 240.13 \mathrm{~d}-5$ (1990)). Apple Bancorp II at *9 n.5. See also Warren and Abrams, 47 Bus. Law. at 663 (cited in note 8 ). The Rights Plan did not restrict the shareholder's "ability to present a slate and to communicate with shareholders; nor [did] it impair the shareholders' ability to vote for [his] slate at the meeting." Apple Bancorp II at *12.

75. Apple Bancorp II at *12.

76. See Blasius Indus., Inc. v. Atlas Corp., 564 A.2d 651 (Del. Ch. 1988). Heightened judicial review of director action designed to impede the franchise required the imcumbents to show a "compelhing justification" for these actions. Id. at 661. For further discussion of the equivalence of the different judicial tests for infringements of the shareholder franchise, see note 88 .

77. Apple Bancorp $I I$ at ${ }^{*} 15$. 
election process requires a judge, the court wrote, to scrutinize carefully director actions impinging on shareholder voting rights. Whenever the stockholder franchise is at issue, "a special obligation falls upon courts to review with care action that impinges upon legitimate election activities."78

However, the rest of the court's opinion showed little deference to the shareholder franchise: it upheld the board's decision to apply the Rights Plan to Stahl's solicitation efforts, first under Moran, and then alternatively under Unocal. ${ }^{79}$ Its Moran analysis was perfunctory. As in Moran, the plaintiff made arguments about the Rights Plan's negative effects on his proxy campaign but failed to introduce any empirical evidence supporting his position. ${ }^{80}$ Based on this shm record, the court found that the Rights Plan's restrictions on revocable voting agreements between shareholders were "immaterial" to the dissident's chances of winning the contest. ${ }^{81}$

In the second part of its Moran analysis, the Apple Bancorp court conducted a highly deferential business judgment type inquiry about the effects of the Rights Plan on the stockholder franchise. ${ }^{82}$ It held that "the Bancorp board could ... have reasonably concluded that the restrictions here addressed would not materially impair the ability of the shareholder to turn out the existing board." ${ }^{33}$ Under this interpretation of the second part of Moran, the board of directors does not even have to show that it considered the impact of the Rights Plan on a dissident's proxy campaign. Not surprisingly, the board's actions were upheld.

\section{Id.}

79. Although the court treated Moran and Unocal as distinct judicial tests, Moran could be collapsed into a Unocal test. See note 68.

80. Commentators cannot fault the court for the plaintiff's failure to introduce sufficient evidence to support his arguments. Faced with this void, the chancellor relied upon Moran's earher determination tbat tbe effect of a flip-over Rights Plans upon the dissident's chances of winning a proxy contest were "minimal." Apple Bancorp II at *18 (cited in note 65). Unfortunately, this finding ignores flip-in Rights Plans' more serious negative impact on a dissident's chances of winning a joint offer. A better approach would have been for the court to appoint its own expert to determine the impact of the flip-in Rights Plan upon a dissident's chances of winning the proxy contest. See notes 241-46 and accompanying text for further discussion of this argument.

81. Apple Bancorp II at $* 20$. While this conclusion has not been tested empirically, the Court's conclusion is debatable. Restrictions on agreements between sharebolders can stop them from taking collective action in proxy contests on such matters as jointly nominating slates of directors or reaching agreements about the reimbursement of expenses. See notes 37-38 and accompanying text. Most Rights Plans also give the target company's board of directors considerable discretion in determining which shareholders are part of the group subjected to the Rights Plan's restrictions. See note 39 and accompanying text.

82. Apple Bancorp II at *18-19.

83. Id. at $* 21$. 
The court then applied the two part Unocal ${ }^{84}$ test, asking whether the board had shown it had reasonable grounds to believe that a threat to the corporation existed, and whether its response to the threat was reasonable. The Apple Bancorp court lield that letting the dissident form revocable voting agreements witl otler shareholders created a threat that the corporation would be taken over without shareholders receiving a premium price for their stock.

The court found, however, that the board's response of using the Riglits Plan to stop Stahl from forming voting agreements witl other shareholders liad an adverse effect on Stahl's ability to wage a proxy campaign. In balancing these two effects to determine the reasonableness of the board's defensive response, the court recognized that the dissident's joint offer might preclude ligher bids from third parties if the Rights Plan were enjoined. The Rights Plan, the court concluded, was "justified in the circumstances by the benefit of preserving to some extent the board's ability to shop the [company]."85 If no alternative bid appeared, stockliolders were likely to vote to accept the tender offer.

Apple Bancorp raises serious doubts about the Delaware courts' commitment to protecting the shareholder franchise from management's defensive tactics. Despite its strong rhetoric concerning the need to protect the franchise, the court's interpretation of Moran's second prong sharply reduced the scope of that decision's protections. Whenever a board can "reasonably conclude" that its actions will not "materially impair" dissidents' ability to win a proxy contest, the court will uploold its defensive actions. While this interpretation of Moran may stop incumbents from creating absolute barriers to dissident victories, ${ }^{\mathbf{8}}$ it would probably permit almost anytling else in a control contest.

The court's Unocal analysis, while acknowledging the effect that incumbents' defensive tactics might have on the outcome of a proxy contest, still gives the board significant discretion in how it responds to

84. The court claimed that in applying the Unocal test it was following the mandates of the Delaware Supreme Court's Moran opinion. See Moran, 500 A.2d at 1350, 1356. The Delaware courts created the Unocal test to apply in situations in which incumhents take defensive actions against hostile tender offers. The Unocal test extended no special protections for the shareholder franchise. It did, however, state that the threat of losing an election contest does not constitute a legally cognizable threat. Warren and Abrains, 47 Bus. Law. at 663-64 (cited in note 8).

The court applied Unocal (and not Blasius) because it found that "the board's refusal to amend the rights plan was not for the primary purpose of impeding, and did not affect adversely, 'the fair exercise of the franclise' of the Apple Bancorp stockholders." Id. at 664, (quoting Apple Bancorp $I I$ ).

85. Apple Bancorp II at *26.

86. See, for example, Sutton, 1991 Del. Ch. LEXIS at *29-39 (striking down a poison pill type retirement plan that barred dissidents from receiving revocable proxies for more than $35 \%$ of the votes in an election of directors). 
a dissident's challenge. At a minimum, a dissident can take some comfort in the fact that the threat of losing an election contest by itself does not constitute a threat under Unocal. ${ }^{87}$ With joint offers, however, the threat posed by a tender offer to a corporation's long-term business strategy is likely, after the Paramount decision, to outweigh a Rights Plan's negative effect on a dissident's election campaign.

\section{c. Summary}

While the rhetoric of the various tests applied to Rights Plans differs, the courts have reached similar results under all of them, ${ }^{88}$ and they seem increasingly to be using the Unocal framework to analyze incumbent defensive tactics in proxy contests. ${ }^{89}$ Under whatever standard that may be used, several conclusions can be drawn.

When a joint offer is at issue, courts have given incumbents considerable leeway in applying Rights Plans against dissident shareholders' proxy solicitation campaigns. After Paramount, if the incumbent board can point to a previously adopted, long-term business plan and argue that it is superior to the dissident's proposed tender offer, then the board can shut down the tender offer part of the joint offer. ${ }^{90}$ Apple

87. Warren and Abrams, 47 Bus. Law. at 663-64 (cited in note 8).

88. For example, the chancellor found tbat tbe Blasius "compelling justification" test is "structurally similar" and "functionally similar" to the Unocal balancing test. Apple Bancorp II at *22-24; Apple Bancorp I at 1124-25 (cited in note 60); Shamrock, 559 A.2d at 286. As the court stated in Apple Bancorp II:

Under either test the board bears a burden to justify its actions. The burden will be greater when the board action is directed specifically and primarily towards the voting process, because that process is the way in which the board itself derives power and thus is of central concern to the corporation and to corporation law.

Apple Bancorp II at *23. The choice of the particular form of judicial review between these two formulations is unlikely to affect the outcome of a case. Id. See Warren and Abrams, 47 Bus. Law. at 669-70 (cited in note 8). Similiarly, a court's choice to apply Moran instead of Unocal does not seem to affect the outcome of its analysis. See, for example, Apple Bancorp $I I$ at ${ }^{*} 23$.

89. The Delaware Supreme Court recently held that when a board "adopts any defensive measure taken in response to some threat to corporate pohicy and effectiveness which touches upon issues of control," such as board action interfering with the exercise of the franchise in a joint offer, "a reviewing court must apply Unocal." Stroud, 606 A.2d at 92 n.3 (quoting Gilbert v. El Paso Co., 575 A.2d 1131, 1144 (Del. 1990)). To the extent that the competing Blasius test retains a separate meaning from Unocal, it means that defensive measures that touch upon issues of control and "purposefully disenfranchise [a target company's] shareholders [are] strongly suspect under Unocal, and cannot be sustained without a 'compelling justification.' " Id. Although the Stroud court did not expressly consider whether Moran differed from Unocal, the court's language about the proper scope of the Unocal test leaves little room for a separate Moran analysis.

90. Paramount will have little effect on the courts' treatment of defensive tactics when the dissidents threaten a change of control solely through the corporate election process: it reaffirms Moran's statement that the stockholders have the ultinate right to vote the incumbent directors out of office if they pursue policies that a majority of stockholders disfavor. Paramount Communications, Inc. v. Time, Inc., Fed. Sec. L. Rep. (CCH) I 94,514 (Del. Ch. July 14, 1989), aff'd, 571 A.2d 1140 (Del. 1989). See also Blasius Indus., 564 A.2d at 663. However, it is also an "authorita- 
Bancorp and Moran allow the target company board to restrict concurrently dissident shareholders' ability to wage an effective proxy contest. ${ }^{91}$ As a result, the target company board can force dissidents to rely completely on the pure proxy contest as a means of pressuring the incumbent board to negotiate a transaction or to push through a change of control.

This makes judicial analysis of defensive tactics in pure proxy contests critical. In the Unocal framework, the courts must address two questions. First, what, if any, threat does a pure proxy contest pose to the corporation? Second, under the second prong of the Unocal analysis, what responses are reasonable to these threats? Part III examines the first of these questions, while Part IV addresses the second question.

\section{What ARe the Justifications for Letting Management Employ Rights Plans in Proxy Contests?}

\section{A. Management's Interest in Protecting the Corporation and Its Shareholders}

Corporate law rests on the fundamental assumption that shareholders hire managers to run their companies and to make decisions about the company's operations and future plans. If they are going to run these businesses effectively, managers need to have some discretion to take actions that they believe will maximize the value of the firms. The shareholders delegate this authority to managers in the belief that managers will act in the shareholders' best interests to increase the value of their holdings. ${ }^{92}$

tive reminder" that an action will need to imphcate directly the stockholder franchise before the courts will invoke heightened judicial scrutiny. Warren and Abrams, 47 Bus. Law. at 654 (cited in note 8). Paramount also permits the board to manipulate the structure of corporate transactions to deprive their stockholders of the opportunity to vote on fundamental corporate changes. Paramount, 571 A.2d at 1146-49.

Nor should Paramount have any effect on a Unocal analysis of proxy contests when control of the board is not at stake. When the dissident is not attempting to gain control of the corporation, as might be the case when institutional investors attempt to elect a minority of the directors to a company's board, then the apphication of a Rights Plan to their proxy solicitation could have "far more than a minimal impact" because it could prevent them from engaging in concerted action to assert their voice in corporate affairs. Gilson and Kraakman, 43 Stan. L. Rev. at $904 \mathrm{n} .145$ (cited in note 17). Furthermore, the company has no offsetting interest in preventing institutions from acting to elect a minority of the board. Id. Similar arguments can be made that certain state antitakeover statutes are triggered by the collective actions of groups of institutional investors. Id.

91. See Part II.C.2. for further discussion of the impact of these cases on a dissident's ability to win a proxy contest.

92. The husiness judgment rule protects managers' and directors' decisions about the conduct of the company's affairs from attack by disgruntled shareholders when the managers and directors act with due care, in good faith, and loyalty. See, for example, Aronson v. Lewis, 473 A.2d 805, 812 (Del. 1984). 
When an outside party threatens to bring about an unsolicited change of control through a tender offer, a well-intentioned management may determine that the proposed transaction is not in shareholders' best interests and rebuff it. A faithful management may have valid concerns about the proposed transaction. For example, the tender offer may discriminate against some shareholders and treat them poorly, it may offer inadequate value to the shareholders for their investment, or it may preclude shareholders from accepting a more favorable alternative transaction. ${ }^{83}$ In each of these instances, loyal management will wish to protect the shareholders and the corporation from harm by using defensive tactics to stop a harmful acquisition.

The difficult issues arise when management takes defensive actions to stop its shareholders from accepting an acquisition offer that shareholders want to accept. While well-intentioned management may have good reasons to keep their shareholders from hurting themselves, ${ }^{94}$ the net effect of the defensive tactics may be to deprive shareholders of their control over their investment.

When a dissident stockholder couples a hostile acquisition proposal with the threat of a proxy contest, as in a joint offer, or the threatened change of control focuses on the election of the board of directors of the company, management may be tempted to use the same defensive tactics to thwart the attempt to remove them from office using the polls. Faithful managers honestly believe that resisting their rivals in the election is in their shareholders' best interests. When, however, their actions impair the ability of shareholders to exercise their franchise effectively, then the courts must critically examine the managers' actions.

Rights Plans have a direct impact on shareholders' free exercise of the franchise; yet, as noted above, the courts generally have deferred to incumbents' decisions to deploy them in proxy contests. Why do the courts permit incumbents to restrict the shareholder franchise through the application of Rights Plans against insurgent shareholders' election campaigns? The answer to this question depends in part on how important the franchise is in the market for corporate control and in part on how strong the justifications are for permitting incumbents to restrict the franchise. These issues are examined separately below.

93. Gilson and Kraakman, 44 Bus. Law. at 267 (cited in note 51).

94. This may be the case when management promises that it will produce greater value in the long run for shareholders than the hostile tender offer but shareholders do not believe that management will deliver on its promise. See id. at 260-65. 


\section{B. The Importance of the Shareholder Franchise in the Market for Corporate Control}

Who controls the corporation is important both to its shareholders and to society because the value of its assets depends significantly on the skill with which they are managed. Bad managers will adversely affect the value of the corporation's assets. However, poor managers cannot be expected to offer generously to give up control over the corporate assets in order to increase social welfare, even if a better management team is identified. ${ }^{95}$ Rather, they usually will fight to retain their offices and perquisites with all available methods. From society's perspective, however, courts should facilitate beneficial control changes despite the incumbents' opposition. ${ }^{96}$

The courts and corporate law theorists have widely recognized the importance of shareholder voting in bringing about changes in the control of the corporation ${ }^{97}$ Free shareholder voting is "critical to the theory that legitimates the exercise of power by some (directors and officers) over vast aggregations of property that they do not own" because it provides the "ideological underpinnings upon which the legitimacy of directorial power rests." ${ }^{98}$ Corporate elections must be conducted "with scrupulous fairness and without any advantage being conferred or denied to any candidate or slate of candidates" if society is to respect the franchise's validity. ${ }^{9 \theta}$ The judiciary accords shareholder voting rights special protections, especially when "directors, bent upon entrenchment, use their authority to restrict the ability of shareholders to replace them." 100

Director action designed to interfere with the franchise alters the allocation of authority between the shareholders and the board that governs the corporation. Limiting the shareholders' voting rights to al-

95. One alternative to removing the existing management team is to give them incentives to perform better by tying their compensation to the firm's performance. Common devices for doing so include stock option plans and performance bonuses.

96. "From a social perspective, facilitating such changes will have two desirable consequences: the beneficial change itself will increase the value of the company ex post, and the threat of losing control may well provide ex ante incentives for incumbents to increase the value of the company." Bebchuk and Kahan, $78 \mathrm{Cal}$. L. Rev. at 1077-78 (cited in note 1). Golden parachutes may be one method of encouraging managers to agree to the sale of a company at a price that the company's shareholders want to accept. Bernard S. Black, Is Corporate Law Trivial: A Political and Economic Analysis, 84 Nw. U. L. Rev. 542, 563 (1990)

97. "Voting rights of shareholders are a major element in the structure of corporate law. . . ." Bebchuk and Kahan, 78 Cal. L. Rev. at 1073. See, for example, Robert Charles Clark, Corporate Law 357-400 (Little Brown, 1986) for a general discussion of the importance of voting rights.

98. Blasius Indus., 564 A.2d at 659.

99. Id. at 661-62.

100. Moran, 490 A.2d at 1080 . 
low the directors to decide what course of action to take presupposes that the directors know better than the shareholders what is best for the corporation. Even if courts accept that presupposition, it does not justify allowing the directors almost absolute control over the election process-"corporation law confers power upon directors as the agents of the shareholders; it does not create Platonic masters."101

In protecting shareholder voting rights, ${ }^{102}$ the courts have drawn on the shareholder democracy model of corporate voting. ${ }^{103}$ In this model, courts consider corporations to be democracies governed through elected representatives. ${ }^{104}$ The ultimate power over the political leadership and over the corporate directorship lies in the individual shareholders' hands and is exercised through the shareholder franchise. ${ }^{108}$ Corporate elections in an ideal shareholder democracy are contests between rival groups that stand in fairly equal positions with respect to their chances to put candidates and questions before the electorate. ${ }^{106}$

101. Blasius Ind., 564 A.2d at 663; see also Durkin v. National Bank of Olyphant, 772 F.2d 55, 59 (3d. Cir. 1985) (interpreting the National Bank Act to hold that "[b]anks do not exist for the purpose of creating an aristocracy of directors and officers which can continue in office indefinitely, immune from the wishes of the shareholder-owners of the corporation").

102. The federal securities laws proxy solicitation provisions were adopted in part to promote shareholder democracy. Dennis S. Karjala, Federalism, Full Disclosure, and the National Markets in the Interpretation of Federal Securities Law, 80 Nw. U. L. Rev. 1473, 1491-92 (1987). Congress and the SEC apparently have adopted the view that shareholders can only exercise their power to control the corporation if they are well-informed before casting their votes. Id. at 1492.

103. See Mortimer M. Caplin, Shareholder Nominations of Directors: A Program for Fair Corporate Suffrage, 39 Va. L. Rev. 141, 150 (1953). Pure shareholder democracy existed, if at all, only in rare cases when ownerslip and control were concentrated in the hands of a few people. Leila N. Sadat-Keeling, The 1983 Amendments To Shareholder Proposal Rule 14A-8: A Retreat From Corporate Democracy?, 59 Tulane L. Rev. 161, 162 (1984). Even though pure shareholder democracy is generally impossible, democratic shareholder participation may provide a desirable counterweight to management's power. For a brief discussion and criticism of this view, see Melvin A. Eisenherg, The Structure of the Corporation: A Legal Analysis 19 (Little Brown, 1976).

104. The model posits that citizens in a democratic society and corporate stockholders are similar. Franklin C. Latcham and Frank D. Emerson, Proxy Contest Expenses and Shareholder Democracy, 4 Case Western Res. L. Rev. 5 (1952). The board of directors stands accountable to the shareholders, as in political democracies, through free and open elections.

105. Why should the political democracy model of shareholder participation provide the necessary check on the unrestrained use of managers' power? One answer comes out of political considerations: shareholder democracy, like political democracy, best preserves the political values of freedom and liberty. Harvey Frank, The Future of Corporate Democracy, 28 Baylor L. Rev. 39, 45-50 (1976).

106. Lateham and Emerson, 4 Case Western Res. L. Rev. at 9 (cited in note 104). Even shareholder democracy's strongest advocates recognized that in practice the existing system fails to meet their goals. Sharelolder democracy advocates believe that lawmakers need to reform the system, much the same way that they propose reforms to the political system to correct that system's abuses. For example, a more democratic system would result if there were more balanced reimbursement provisions for campaign expenditures, better procedures for shareholders to nominate candidates for directorships, greater access to the management proxy statement for shareholder proposals, and greater dissemination of more information about the corporation and the candidates for directorships. If lawmakers made these reforms, proponents of this model claim, 
The shareholders can exercise a free choice between these contestants to select the best group. Proxy contests give shareholders the right to remove unwanted management: "Obviously, the very essence of such type of democratic economic organization is the availability to the shareholders of the untrammeled right of recall, at least on an annual basis, over those managers whose records are not found to be satisfactory." 107 The courts should zealously protect the shareholders' right to vote, and the right to participate freely in corporate elections, against the incumbents' attempts to restrict it.

As influential as the shareholder democracy model has been, its theoretical validity is open to question. ${ }^{108}$ The model focuses excessively on the power of the small shareholder. Modern corporations may have thousands of small shareholders, widely dispersed in location, but those thousands generally hold only a small fraction of the company's stock. The power of larger institutional investors swamps that of the small stockholder. ${ }^{109}$

Courts can more aptly analyze the voting power of institutional shareholders using the shareholder monitoring model. This model gives voting an important place among the constraints on managerial misconduct, but discards the political election analogy of the shareholder democracy model. ${ }^{110}$ In the monitoring model, voting is one of the

they would revive shareholder democracy as shareholders found that they had a meaningful opportunity to participate in corporate elections. Compare Daniel R. Fischel, The Corporate Governance Movement, 35 Vand. L. Rev. 1259, 1275 (1982).

107. Caplin, 39 Va. L. Rev. at 151 (cited in note 103). The arguments here are similar to those made by Lowenstein with respect to dual class recapitalizations. Louis Lowenstein, Shareholder Voting Rights: A Response to SEC Rule $19 c-4$ and to Professor Gilson, 89 Colum. L. Rev. 979,1010 (1989). Lowenstein argues that if corporate governance is to approximate the system of governance utilized in the political realm-namely democracy-then votes should not "he routinely traded away in private transactions [such as recapitalizations], hecause of a deep and ahiding fear of power without accountability."

108. For example, some critics of this model note that despite all of the rights and powers held by shareholders, and legal reforms designed to inform shareholders, shareholders continue to show little interest in running the corporation's affairs or in voting in its elections. Fischel, 35 Vand. L. Rev. at 1274 (cited in note 106). For several other criticisms of the shareholder deinocracy model, see Daniel R. Fischel, Organized Exchanges and the Regulation of Dual Class Common Stock, 54 U. Chi. L. Rev. 119, 141 (1987); William Irvine, Corporate Democracy and the Rights of Shareholders, 7 J. Bus. Ethics 99, 107 (1988).

109. Professor Conard argues that the "idea was doomed from the start" if its focus rests solely on the role of individual shareholders, because institutional shareholders already hold the majority of puhhicly held equity securities. Alfred Conard, Beyond Managerialism: Investor Capitalism, 22 U. Mich. J. L. Ref. 117, 127-28 (1988).

110. This model postulates that the shareholder-manager relationship is a principal-agent relationship. The principal needs to monitor the conduct of the agent to insure that the agent continues to act in the principal's best interests. "Shareholder monitoring is one strand in a web of imperfect constraints on corporate managers." Black, 39 U.C.L.A. L. Rev. at 831 (cited in note 17).

The shareholder monitoring model could be descrihed more accurately as involving disciphne of management rather than just monitoring. As Professor Rock points out, "effective oversight 
mechanisms by which the principals of the corporation, the shareholders, monitor the performance of their agents, the directors and officers. ${ }^{111}$ Institutional shareholders are well-placed to act as monitors because of their greater stake in the company. ${ }^{112}$

The potential benefits of institutional investor monitoring have been well-documented. ${ }^{113}$ Institutional investors could help correct systematic shortfalls in corporate performance and add value for shareholders in several ways. These include demanding increased director independence, ${ }^{114}$ decreased corporate diversification, ${ }^{115}$ improved takeover bidding, ${ }^{116}$ better corporate governance rules, ${ }^{117}$ improved utiliza-

requires more than monitoring management's performance; it requires doing something about suboptimal performance." Rock, 79 Georgetown L. J. at 453 (cited in note 17).

111. Otber monitoring mechanisms include the use of outside directors and independent auditing firms to evaluate incumbent managements' performance, institutional shareholders' informal suggestions, and formal shareholder proposals about corporate governance issues. See, for example, Black, 39 U.C.L.A. L. Rev. at 824; Thomas Andre, A Preliminary Inquiry Into The Utility Of Vote Buying in the Market for Corporate Control, 63 S. Cal. L. Rev. 533, 625 (1990).

112. Of course, the term "institutional investor" masks the significant differences between the many different types of institutions and their abilities to monitor management effectively. For an interesting discussion of these differences and their effect on the effectiveness of shareholder monitoring, see Black, 89 Mich. L. Rev. at 596-604 (cited in note 17).

113. See generally, Black, 39 U.C.L.A. L. Rev. at 895 (cited in note 17); Bernard S. Black, Disclosure, Not Censorship: In Support of Proxy Reform, 17 J. Corp. L. 49 (1991); Jayne W. Barnard, Institutional Investors and the New Corporate Governance, 69 N.C. L. Rev. 1135 (1991); Richard Buxbaum, Institutional Owners and Corporate Managers: A Comparative Perspective, 57 Brooklyn L. Rev. 1 (1991); Rock, 79 Georgetown L. J. at 445 (cited in note 17); George Dent, Toward Unifying Ownership and Control in the Public Corporation, 1989 Wis. L. Rev. 881 (1989); Coffee, 91 Colum. L. Rev. at 1277 (cited in note 17).

114. Black claims that the (scanty) available evidence shows that independent directors are valuable. Black, 39 U.C.L.A. L. Rev. at 902. If he is right, then institutional investors can increase the value of firms by pushing for a majority of independent directors on the board, independent nominating committees, appointment of institutional directors, and reductions in the CEO's authority to select directors. Id.

115. Corporate diversification strategies consistently have created negative value for acquirers. Institutional investors who already are diversified across companies are ideally placed to urge companies to stop making conglomerate acquisitions and to divest unrelated divisions or subsidiaries. Id. at 905 .

116. In the 1980s many takeover bidders experienced stock price declines from acquisitions. While these negative returns by themselves do not indicate the transactions were socially undesirable, in a large percentage of cases they exceeded target company gains. Id. at 908 . Institutional investors with diversified portfolios have investments in botb companies and can be expected to study these acquisitions closely. They will object when they believe that a transaction will decrease the value of their portfolio. If institutions can identify factors that will make for negative value acquisitions, they can push to stop these transactions. Id. at 909-10. The converse should also be true.

117. Many companies have antitakeover charter and by-law provisions that reduce the frequency of takeover bids and make it more likely that the target will succeed in defeating an offer. As institutional investors gain more strength, they may be able to remove some of these provisions and prevent their proliferation. Id. at 911 . Similarly, institutions can lobby against state antitakeover legislation that stops takeovers or push companies to opt out of the statutes. Id. at 911-12. 
tion of free cash flow, ${ }^{118}$, and changes in the existing system for calculating executive compensation. ${ }^{119}$ Institutional oversight can best police these corporate failings because "diversified institutions can realize economies of scale in acting to overcome them at a number of portfolio companies." 120 The existing direct evidence on the effects of institutional shareholder monitoring, while sketchy, suggests that these changes could raise stock prices significantly. ${ }^{121}$

Sliareholder monitoring helps keep "companies from wandering too far off the profit path."122 Shareholders can go to the polls to limit management's ability to institute antitakeover devices, such as the Rights Plan. ${ }^{123}$ Outside directors that owe their loyalty to shareholders will act sooner to remove poor managers. Ultimately, if shareholders believe that the incumbent management is performing poorly, and the board fails to replace them, the dissatisfied shareholders can bring a proxy

118. Corporate managers may hoard cash and spend it unwisely. Institutions could discourage this overspending in favor of more prudent cash reserves and encourage companies to return the excess amounts to their shareholders. Id. at 914-15.

119. Institutional investors insisting on the creation of a more arm's length negotiation process in the calculation of executive pay could temper recent widespread criticism of executive pay. Id. at 916-17.

120. Id. at 898.

121. Id. at 895 . In addition, research on oversight by large shareholders, although it does not discriminate between inside ownership and outside ownership, "suggests a generally positive link between concentrated ownership and corporate performance." Id. at 917. Similarly, evidence from leveraged buyout transactions in this country and information about the impact of institutional investors suggest that large shareholder monitoring is valuable. Id. at $925-26$. Finally, comparisons with other countries' corporate governance structures seem to show that financial intermediary monitoring creates value. Id. at 928 . See generally Mark J. Roe, Some Differences in Corporate Governance in Germany, Japan and America, 102 Yale L. J.___ (1993) (forthcoming); Ronald J. Gilson and Mark J. Roe, Understanding The Japanese Keiretsu: Overlaps Between Corporate Governance and Industrial Organization, Stanford Law and Economics, Working Paper No. 97 (August 1992).

122. Black, 39 U.C.L.A. L. Rev. at 823 (cited in note 17). Recent successes of institutional investors in forcing management changes or shake-ups at several major American companies, including General Motors, demonstrate dramatically the power of these institutions. See Pound, Wall St. J. at A10 (cited in note 13).

123. Sbareholders can benefit from antitakeover devices if the devices increase managers' bargaining power with potential acquirers and thereby raise the price that shareholders receive in a tender offer or if the devices prevent a coercive tender offer. However, management can use these same devices to insulate themselves from the threat of takeover when their company's performance is weak. Stock prices, reflecting the net movement of these two effects, show statistically significant decreases from the introduction of a variety of antitakeover devices. See, for example, Michael Ryngaert, The Effect of Poison Pill Securities on Shareholder Wealth, 20 J. Fin. Econ. 377 (1988); Paul H. Malatesta and Ralph A. Walkling, Poison Pill Securities: Stockholder Wealth, Profitability and Ownership Structure, 20 J. Fin. Econ. 347 (1988); Gregg A. Jarrell and Annette B. Poulsen, Shark Repellants and Stock Prices: The Effects of Antitakeover Amendments Since 1980, 19 J. Fin. Econ. 127 (1987); Gregg A. Jarrell and Annette B. Poulsen, Dual Class Recapitalizations As Antitakeover Mechanisms: The Recent Evidence, 20 J. Fin. Econ. 129 (1988). 
contest to persuade other shareholders to remove the board and existing management. ${ }^{124}$

Proxy contests (or the threat of them) increase incumbent management's responsiveness to its shareholders. ${ }^{125}$ Managers are more likely to hear and to act on investors' demands for meetings and requests for changes in corporate policies if managers fear the consequences of alienating investors than if managers are insulated from removal from office. This is especially true with institutional investors who increasingly have engaged in dialogues with corporate managements about improving corporate performance. ${ }^{128}$ Strong management defensive tactics in proxy contests that tilt the election field even further in management's favor will undoubtedly make them less responsive to institutional investors.

A third competing theory of corporate voting, the contractarian model, ${ }^{127}$ emphasizes the importance of voting in fleshing out the details of the parties' corporate contract. ${ }^{128}$ Voting has value primarily because it facilitates takeovers. ${ }^{129}$ When there is no threatened change of

124. Bebchuk and Kahan, Proxy Contests, 78 Cal. L. Rev. at 1078 (cited in note 1).

125. See, for example, Steven Schulman, The Cost of Free Speech in Proxy Contests for Corporate Control, 20 Wayne L. Rev. 1, 31-32 (1973).

126. See, for example, Pound, Wall St. J. at A10 (cited in note 13); Black, 39 U.C.L.A. L. Rev. at 848 (cited in note 17).

127. The contract theory of corporate voting begins with the preinise that corporations are a great web of contracts. Legal rules serve several functions in facilitating the contracting process: corporate codes act as standard form contracts that can reduce the costs of negotiating contracts between the parties. See, for example, Frank Easterbrook and Daniel Fischel, Close Corporations and Agency Costs, 38 Stan. L. Rev. 271, 282 (1986); John Coffee, No Exit?: Opting Out, The Contractual Theory of the Corporation, and the Special Case of Remedies, 53 Brooklyn L. Rev. 919, 932 (1988); Lucian Bebchuk, The Debate on Contractual Freedom in Corporate Law, 89 Colum. L. Rev. 1395, 1397 (1989); Jonathan R. Macey, Corporate Law and Corporate Governance: A Contractual Perspective, 18 J. Corp. L. (1993) (forthcoming).

128. The leading proponents of this theory argue that " $[t]$ he right to vote is the right to make all decisions not otherwise provided by contract." Frank H. Easterbrook and Daniel R. Fischel, Voting in Corporate Law, 26 J. L. \& Econ. 395, 402 (1983). Voters elect directors and give them discretion over many things because voting is expensive and shareholders want to conserve on its use.

Existing state corporate laws provide investors with different choices of voting arrangements that they generally would find desirable if they could arrange and enforce contracts at low cost. Corporate voting forms evolve through competition, with the methods that deliver what the shareholders want at the lowest cost surviving. See Easterbrook and Fischel, 26 J. L. \& Econ. at 416, 418-19 (saying that the most efficient corporate law rules, including voting rules, will survive); Dennis Carlton and Daniel R. Fischel, The Regulation of Insider Trading, 35 Stan. L. Rev. 857, 860 (1983); Daniel R. Fischel and Michael Bradley, The Role of Liability Rules and the Derivative Suit in Corporate Law: A Theoretical and Empirical Analysis, 71 Cornell L. Rev. 261, 274 (1986).

129. Henry Manne, Mergers and the Market for Corporate Control, 73 J. Pol. Econ. 110 (1965); Henry Butler and Larry Ribstein, The Contracts Clause and the Corporation, 55 Brooklyn L. Rev. 767, 772 (1989). Easterbrook and Fischel offer several other reasons why voting has value, including evidence that proxy contests produce price increases for the target's stock even if the dissidents do not win. Easterbrook and Fischel, 26 J. L. \& Econ. at 406-07 (cited in note 128); 
control, either implicitly or explicitly, voting is of little consequence..$^{130}$ In a tender offer, an acquirer accumulates shares in a firm, then exercises its voting rights to take control of the firm. ${ }^{131}$ Without voting rights for shares, tender offers could not succeed..$^{132}$ Obviously, voting rights also are central to the success of a proxy contest for corporate control, for without them shareholders would have no method for electing a new board.

Each of these three models-the shareholder democracy model, the monitoring model, and the contractarian model-recognizes the importance of the free exercise of the shareholder franchise in change-of-control situations. Why then do the courts continue to approve management's use of defensive tactics that infringe on shareholder voting?

\section{The Uncertain Case for Permitting Defensive Tactics in Proxy Contests}

\section{Argument 1: Inferior Dissidents Win Proxy Contests Because of Information Imperfections}

Bebchuk and Kahan have argued that shareholders have inadequate information to determine which contestant is superior in a proxy contest and, therefore, inferior dissidents may emerge from a proxy

Frank H. Easterbrook and Daniel R. Fischel, The Economic Structure of Corporate Law 67, 70-72 (Harvard, 1991).

Proxy contests play a disciplinary role of policing management's performance. Fischel, $54 \mathrm{U}$. Cli. L. Rev. at 133-34 (cited in note 108). Corporate officers' lack of tenure gives sliareholders the power to throw out the directors if the agency costs associated with their management of the company become unacceptable. "The right to vote provides shareholders with the opportunity to decide whether their agents have performed well enough to continue in office." Id. at 133.

130. In uncontested elections, the contract theory claims that shareliolders rubberstamp management's candidates for directorships because economic forces "compel managers to maximize profits as shareholders would if they controlled the firm." Dent, 1989 Wis. L. Rev. at 885 (cited in note 113). Monitoring of management takes place primarily through these institutional constraints, and only weakly througl shareholder voting. Fischel, $54 \mathrm{U}$. Cli. L. Rev. at 133 (cited in note 108). Otleers have disputed this view of the economic constraints on managers. See, for example, Black, 39 U.C.L.A. L. Rev. at 811 (cited in noto 17); Dent, 1989 Wis. L. Rev. at 886-92. Of course, the threat of a change of control can be implicit, in which case voting can persuade managers to cliange their policies even when dissidents have made no express threat of a proxy contest.

131. Easterbrook and Fischel, 26 J. L. \& Econ. at 402-03 (cited in note 128). Corporate acquirers will accumulate shares in a poorly managed firm and exercise their voting rights to take control of the corporation. Id. at 402-03. See also Easterbrook and Fiscliel, The Economic Structure of Corporate Law at 67 (cited in note 129).

132. The success of a tender offer depends heavily on voting rights. "For a tender offer to succeed and be a socially useful mechanism, several conditions must be satisfied: (1) there must be voting rights; (2) they must be susceptible to being bought and sold (along with the shares that lave them, usually); and (3) their purchaser must be able to obtain a reward for having expended funds to obtain control." Clark, Corporate Law at 398 (cited in note 97). 
contest as winners. ${ }^{133}$ Their argument rests on two premises: first, that the shareholder profile of companies involved in proxy contests is comprised largely of shareholders whose wealth will not be affected greatly by the outcome of the contest; and second, that "these shareholders will consider it unlikely that their few votes will affect the outcome of the control contest."134 Shareholders will therefore lack incentives to become informed and fail to select rationally the best candidates. ${ }^{135}$

Looking first at the modern corporation's shareholder profile, the empirical evidence shows that large shareholders control most of the major publicly traded companies' stock and that these shareholders' ownership percentage has increased rapidly over the last decade. By 1990, institutions held more than fifty-three percent of the total publicly held equities in the United States, with pension funds alone controlling more than twenty-eight percent of equity securities. ${ }^{136}$ Individual shareholders' percentage holdings have fallen sharply over the same time period.

This data make the importance of the institution's vote in proxy contests obvious. ${ }^{137}$ Adding the institution's holdings to those of other large blockholders, and the participants in the contest, these stockholders may own as much as ninety percent or more of a target company's stock. ${ }^{138}$ Although each of these shareholders may control only a small

133. See Bebchuk and Kahan, 78 Cal. L. Rev. at 1080-81 (cited in note 1).

134. Id. at 1080 .

135. Id. at $1080-81$.

136. Black, 38 U.C.L.A. L. Rev. at 827 (cited in note 17). This marks a $15.3 \%$ increase in institutions' share of total U.S. market capitalization in the period from 1981 to 1990 . See also Rock, 79 Georgetown L. J. at 447 (cited in note 17).

137. Pound's data for 1981-1985 show that for his entire sample of 100 contests, institutional stock ownership averaged approximately $20 \%$. Pound, $29 \mathrm{~J}$. Fin. Econ. at 252 (cited in note 2). Borstadt and Zwirlein find that institutional investors held on average over $18 \%$ of the target companies' shares in a sample of 142 proxy contests for the period from 1962-1986. Lisa F. Borstadt and Thomas J. Zwirlein, The Efficient Monitoring Role of Proxy Contests: An Empirical Analysis of Post Contest Control Changes and Firm Performance, Working Paper at 9 (Sept. 1990). More recent data show a large increase in institutional shareholdings in target companies. In a study of 343 proposed antitakeover amendments using data from 1985-1988, the average institutional ownership of the sample companies was over $40 \%$. Philip J. Young, James A. Millar, and G. William Glezen, Shareholder Voting: The Impact of Ex-Voting Date Trading Volume, Meeting Date Lag, and Management Solicitation Efforts at 22, Table 3. Thomas and Martin find that for 89 proxy contests from 1985-1991, the average level of institutional shareholdings in target companies was $37.9 \%$. Randall S. Thomas and Kenneth J. Martin, The Impact of Poison Pills on Proxy Contests: An Empirical Analysis, Working Paper, at 29, Table 2 (1992) (on file with author).

138. Besides the institutions, other large groups control significant percentages of the target companies' stock. For instance, Pound's study shows that $5 \%$ blockholders on average hold another $10 \%$ of the companies' stock, while management and dissidents collectively hold another $20 \%$ on average. Pound, $29 \mathrm{~J}$. Fin. Econ. at 252 (cited in note 2). When foreign shareholders, who frequently owm another $6 \%-10 \%$ of many companies' stock, and who generally do not vote in proxy contests, are ehminated, the percentage stock holdings of other investors in most target companies can be quite small. 
percentage of the target company's stock, ${ }^{139}$ the dollar amount of their investments are frequently many millions of dollars. In these circumstances, rational shareholders will become informed and vote in what they perceive to be a wealth-maximizing fashion. ${ }^{\mathbf{1 4 0}}$

Large shareholders will have greater incentives to become informed in a proxy contest. A shareholder with 1000 shares is 1000 times more likely to cast the decisive vote than one with one share, and will capture 1000 times the gain if its vote is decisive. ${ }^{\mathbf{1 4 1}}$ If the gains realized by an institutional shareholder are multiplied by the probability its vote will be decisive in the contest, the result shows how an institution's incentives to make an informed vote increase exponentially with the number of shares it owns.

The current popularity of joint offers, and the larger size of the targets of proxy contests, ${ }^{142}$ also increase the likelihood that target company shareholders will carefully consider their votes. When the companies are publicly traded, individual institutions typically own shares in both the target and the bidder. In deciding how to cast their votes, they weigh the net impact of the proposed transaction on the value of their portfolio. ${ }^{143}$ Even if the price offered for the target companies' stock

139. As Professor Black points out, a number of legal obstacles make it hard for any shareholder to accumulate a large percentage of a company's stock. Black, 39 U.C.L.A. L. Rev. at 822-24 (cited in note 17).

140. "Institutions are more likely than other shareholders to vote at all, more likely to vote against manager proposals, and more likely to vote for proposals by other shareholders." Id. at 926. See also John Pound, Shareholder Activism and Share Values: The Causes and Consequences of Countersolicitations Against Management Antitakeover Proposals, 32 J. L. \& Econ. 357, 358 (1989).

Bebchuk and Kahan appear to concede tliat the rise in institutional sliareholdings lias reduced the severity of the information problem. See Bebchuk and Kahan, $78 \mathrm{Cal}$. L. Rev. at 1082 (cited in note 1). Their analysis, lowever, stops short of the arguments made here.

141. Black, 39 U.C.L.A. L. Rev. at 822 (cited in note 17).

142. In 1991, the largest transaction in the mergers and acquisition field was AT\&T's successful $\$ 6$ billion joint tender offer for NCR and proxy contest that led to a negotiated merger of the two companies. More generally, Georgeson's 1990 Proxy Contest Study slows siguificant increases in the percentage of proxy contests involving companies witl assets of over $\$ 250$ million. In $1986,25 \%$ of target companies liad assets valued at inore than $\$ 250$ million. This percentage rose to $43 \%$ in $1987,61 \%$ in $1988,56 \%$ in 1989 , and $61 \%$ for the first nine months of 1990 . Georgeson \& Co., Proxy Contest Study, at 22, 24, Fig. 10 and 13 (cited in note 4). While analysts can attribute part of this trend toward bigger targets to the impact of inflation on asset values, it seems clear that proxy contest targets are getting bigger.

143. Black, 39 U.C.L.A. L. Rev. at 909-10 (cited in note 17). For example, in the NCR and AT\&T proxy contest many institutions lield stock in botll companies. The Institutional Sharelolder Services, Inc. Proxy Analysis projected that AT\&T's joint offer would have the effect of raising NCR's stock price but reducing AT\&T's stock price. Institutional Shareholder Services, NCR Corp. Proxy Analysis, Vol VI, No.33 (Marcli 11, 1991). It recommended to its clients, many of tbe major institutions in the country, that

... if the market value of your AT\&T shares as of Marclı 1, 1991 (the record date for the NCR meeting) was at least five times as mucl as the market value of your NCR boldings on 
exceeds its current market price, any decline in the bidder's stock will offset this gain. If the net effect of the transaction decreases the value of the institutions' portfolios, they will register their disapproval of the offer through direct methods (voting against the dissident slate) ${ }^{144}$ and indirect methods (pressuring the bidder to drop the offer). ${ }^{145}$

The trend toward larger targets of proxy contests will further increase the likelihood of better informed shareholder voting. For one thing, larger companies tend to have a lighler percentage of their stock leeld by institutions, especially if they participate in one of the widely publicized stock market indices. ${ }^{146}$ Legal rules lead these shareholders to consider carefully the merits of the contestants' positions. The institutional shareliolders liave fiduciary duties to vote in their beneficiaries' best interests in a proxy contest. ${ }^{147}$ They must scrutinize the positions of the opposing camps to fulfill these duties. Many institutions have developed special committees or groups that decide which group to vote for. Other institutions rely on outside specialists for recommendations about which side they should support in ongoing proxy battles. ${ }^{148}$

the same date, we think that your net returns will be negative, and recommend that you vote

against the AT\&T slate. Otherwise, we recommend that you vote in favor.

Id. at 9.

For a discussion of the effects of investor diversification on corporate control transactions, see generally Frank H. Easterbrook and Daniel R. Fischel, Corporate Control Transactions, 91 Yale L. J. 698, 711-14 (1982); Frank H. Easterbrook and Daniel R. Fischel, Auctions and Sunk Costs in Tender Offers, 35 Stan. L. Rev. 1, 7-9 (1982).

144. In circumstances in which they hope that the dissidents will obtain only minority representation, some institutions have split their votes between dissidents and incumbents. Black, 39 U.C.L.A. L. Rev. at 846 .

145. The AT\&T-NCR contest is a good example of how institutions holding stock in both the target and the bidder can try to stop the deal. Some institutions voted against the AT\&T slate of candidates because they thought the transaction would have the net effect of reducing AT\&T's value by more than the increased value of NCR. Id. at 910 . Other institutions looked only at the NCR takeover premium and voted in favor of the takeover. Id.

146. Black, 39 U.C.L.A. L. Rev. at 856. Many institutions hold portfolios that consist of all of the stocks in one of the well-known market indices, such as the Dow Jones Industrial Index or the Standard and Poor's 500. James A. White, Pension Funds Think Less May Be More, Wall St. J. C1 (Oct. 23, 1991). This strategy of buying a basket of stocks whose performance mirrors that of the market permits the institutions to keep pace with the market while insuring that their transaction costs remain low.

147. Black, 39 U.C.L.A. L. Rev. at 856-57. For an in-depth treatment of the legal issues that arise out of proxy voting by institutional shareholders, see generally Dan M. McGill, ed., Proxy Voting of Pension Plan Equity Securities (Irwin, 1989).

148. For example, many institutions, such as Wells Fargo, a large index fund manager, rely on proxy contest analyses pubhished by the Proxy Advisory Service of Institutional Shareholder Services, Inc. for recommendations on how they should vote in proxy contests. Black, 39 U.C.L.A. L. Rev. at 855 . These proxy analyses contain historical information about the target company, details of interviews of both dissident groups and incumbent management, and Institutional Shareholder Service's analyses of the two sides' positions. See, for example, 7 Jefferson-Pilot Proxy Analysis 8-22 (April 17, 1992). See also Victor F. Zonana, Activist Shareholders Spur Growth Of A New Kind Of Advice Industry, L.A. Times D3 (July 21, 1991). 
Information about these large target companies is generally easily accessible. Larger target companies receive greater media coverage of their proxy contests because the press considers them more newsworthy. More valuable corporate assets also could justify greater expenditures by the dissidents to inform the shareholders, and the public, of their position. ${ }^{149}$

Finally, the costs of obtaining good information about proxy contests are comparatively low. Proxy contests are relatively rare, averaging about twenty-eight a year over the past ten years. The number of contests any institutional shareholder is likely to be involved in is likely to be low..$^{180}$

Information about the relative merits of both parties' positions is readily available. Both contestants have every incentive to develop their most convincing arguments, and to expose the weaknesses of the other side's position. In a close election, shareholders can expect contestants to contact them several times and to provide extensive information about both sides' business plans, credentials, and past accomplishments. To the extent that the contestants' materials are defective, the media and third-party services offer their own analyses. ${ }^{151}$

Nevertheless, any shareholder that does not own all of the company's shares may have "inadequate information incentives." 182 If some shareholders are not well-informed about the merits of the two sides in a proxy contest, sound public policy points toward encouraging them to become better informed. The courts should carefully scrutinize any barrier to better dissemination of information. ${ }^{16 s}$

149. Management faces almost no constraints on the amount that it can spend in defending against a proxy contest because the corporation invariably will reimburse its expense. Dissidents will have greater incentives to spend more on the contest when they believe that they will realize greater gains from a victory. Everything else being equal, this is more likely to be true if the value of the target company's assets is high than if the target's assets are worth little.

150. Georgeson \& Company, Inc., Proxy Contest Study, at 22, Table 10 (cited in note 4).

151. See note 148 for further discussion.

152. Bebchuk and Kahan, $78 \mathrm{Cal}$. L. Rev. at $1080 \mathrm{n} .30$ (cited in note 1).

153. Bebchuk and Kahan express a related concern: that proxy contestants will be subject to imperfect incentives to enter contests. Id. at 1081. Under existing laws, a dissident group faces a significant risk of losing the contest and bearing all of the costs of its campaign. If it wins, however, the group gets only its pro rata share of the gains from its improved management team with other shareholders receiving the remainder of these benefits. Balancing these costs and benefits will deter rational dissidents from entering some contests when society would benefit from their intervention. Bebchuk and Kahan propose revising the proxy contest expense reimbursement rules to eliminate this disincentive. Id. at 1106-26.

The presence or absence of defensive tactics influences the entry decision. Lax legal rules regulating defensive tactics will reduce dissidents' chances of winning proxy contests and lower the likelihood of their commencing a proxy contest. Id. at 1104 n.122. Although a thorough investigation of dissidents' decisions to enter a proxy contest is beyond the scope of this paper, a researcher could apply Bebchuk and Kahan's framework for analyzing entry decisions to examine the interaction of the entry decision and defensive tactics. 
Rights Plans (and other defensive tactics) can obstruct the flow of information between dissident groups and other shareholders. ${ }^{154}$ Nonaligned shareholders may avoid contacting dissident groups about pending proxy contests for fear of becoming involved in litigation concerning the reach of a Rights Plan. ${ }^{15 s}$ Furthermore, the broad scope of beneficial ownership in Rights Plans, and the possibility of inadvertently triggering the plan through group activity, will make other shareholders think twice before contacting a dissident group to ask for more information about their plans.

In sum, commentators have greatly overstated the importance of the "inadequate information" problem in recent proxy contests. Changes in the shareholder profile of most companies and the increased use of joint offers have led to a more informed shareholder electorate. To the extent that information problems persist, permitting incumbents to use Rights Plans against dissident groups may exacerbate these problems.

\section{Argument 2: Self-Enriching Small Shareholders Win Proxy Contests}

A second argument made in favor of management defensive actions in proxy contests is that dissident groups may be comprised of small shareholders who lack the proper incentives to maximize total shareholder wealth. ${ }^{158}$ Victorious small shareholders may put inferior, dishonest managers into office if these shareholders stand to gain more from siphoning off side payments and perquisites from the target company than they would lose from the resulting diminution of their stock's value. ${ }^{187}$ Large shareholders that have a greater portion of their

154. See notes 40-41 and accompanying text for further discussion of Rights Plans' impact on the dissemination of information about proxy contests. The courts also could view Rights Plans as calculated efforts by managers to provide disinformation because they pretend to give "rights" to shareholders when in fact they have the opposite effect.

155. For further discussion of how this problem impacts on proxy contests, see notes 42-47 and accompanying text (analyzing the proxy contest between Avon and Chartwell).

156. Easterbrook and Fischel, 26 J. L. \& Econ. at 413 (cited in note 128). There is one important caveat to this argument: it is limited to cases in which the incumbents control more of the target company's stock than the dissident group. Only in this situation will the incentives for the incumbents to maximize the total value of the company exceed those of the dissidents. In fact, available statistical data show that, for those companies that experience proxy contests, average dissident stockholdings are more than twice as large as those of incumbent managers. Thomas and Martin, Working Paper at 29, Table 2 (cited in note 137).

157. Easterbrook and Fischel, Economic Structure of Corporate Law at 77 (cited in note 129). Easterbrook and Fischel claim that the market normally will insure that these contestants will be defeated because those who believe the stock is overpriced, and who might agree with the dissidents that the company is mismanaged, will sell their shares. The remaining stockholders will have relatively homogeneous (positive) expectations about the firm's performance, making it difficult to persuade them to vote for a change. Easterbrook and Fischel, 26 J. L. \& Econ. at 414-15. 
wealth tied up in the company are more likely to work to improve management and to make needed investments because they stand to capture a larger portion of the resultant gains. ${ }^{168}$

While victories by self-dealing small shareholders are possible, they are unlikely. For a dissident group to have a realistic chance of winning a proxy contest, it must either control a very sizeable block of the company's stock, ${ }^{159}$ or convince other shareholders that it is preferable to existing management. If the dissidents hold a large enough block of the company's stock to win the contest with little help from other shareholders, their incentives to maximize their personal wealth should be closely aligned with maximizing the company's share price. In all other cases, dissidents will need to convince the other shareholders that their business plan is solid, that they are not going to loot the company, and that incumbent management is incompetent.

Even when a dissident succeeds in getting its message out to the other shareholders, the incumbent enjoys an advantage in a close contest. If the relative merits of the two sides' positions appear equal, many shareholders vote for management. ${ }^{160}$ A combination of apathy, and the seemingly smaller downside risks of voting for management, "the devil they know," may explain many shareholders' tendency to vote for the incumbents. The incumbents' many advantages in proxy contests may explain the rest: incumbents set the date for the shareholder meeting and the record date for determining which shareholders are entitled to vote at the meeting, they have preferred access to the stockholder lists, they receive unlimited reimbursement of their solicitation expenses, they have established goodwill among their shareholders through their previous contacts or other business connections with shareholders, and they have control over the nomination process and the agenda for the meeting. ${ }^{181}$ When a dissident group appears likely to

158. Id. at 415. Large shareholders capture a greater percentage of the gain from improving the firm's perfornance hecause they have a larger equity stake. This increases the likelihood that they will bring a proxy contest to remove poor unanagers and improve corporate performance, and not to capture side payments and perquisites.

159. Pound's study of 100 proxy contests (including issue contests) during the period of 1981-1985 found that dissidents' average stockholdings were about $12 \%$ of the total equity of the target company. Pound, 20 J. Fin. Econ. at 252 (cited in note 2). Thomas and Martin's inore recent study of proxy contests found that average dissident stock ownership was $11.4 \%$. Thomas and Martin, Working Paper at 29, Table 2 (cited in note 137).

160. Small sliareholders overwhelmingly favor incumbents in most proxy contests. Gilson and Black, Finance of Corporate Acquisitions at 453 (cited in note 14). Institutional sliareholders also generally vote for the incumbents, Pound, 32 J. L. \& Econ. at 371 (cited in note 140), although more recent data suggest that this effect is less significant today, Thomas and Martin, Working Paper at 25.

161. Bebchuk and Kahan, $78 \mathrm{Cal}$. L. Rev. at 1084-85 (cited in note 1); Pound, 32 J. L. \& Econ. at 362-63. See Melvin A. Eisenberg, The Structure of the Corporation at 97-127 (cited in 
win, incumbents can often stave off defeat at the last minute by embracing the dissident platform as their own. ${ }^{162}$

To win, dissidents must convince the more sophisticated, larger investors, usually the institutional investors, that they will be better off with the dissidents in control of the company. These investors are likely to scrutinize carefully the composition of the dissident group and the merits of its proposals. ${ }^{103}$ High quality management teams should have little to fear from dissident proxy solicitations. ${ }^{104}$ Even if shareholders believe that the dissident management team will be superior, many institutional investors are subject to various pressures to vote for the incumbent management. ${ }^{168}$ If a dissident group of small shareholders can win the contest in the face of these obstacles, society seems to have little need for permitting incumbent inanagement to use defensive tactics, such as Rights Plans, to "protect" the other shareholders.

\section{Argument 3: Proxy Contests Decrease Social Wealth}

Many commentators have dismissed proxy contests as ineffective and inefficient disciplinary mechanisms. ${ }^{168}$ If existing empirical studies showed that proxy contests are inefficient, that is, they decrease social wealth, they would provide an efficiency-based justification for allowing incumbents to impede dissidents' efforts to win proxy contests. ${ }^{167}$ The available empirical studies do not measure the social wealth effects of

note 103). Some other advantages include the following: Shareholders are reluctant to vote for the "devil they don't know," especially small, less-diversified shareholders, and management controls the reporting of net profits and frequently dresses them up to look better. Linda E. DeAngelo, Managerial Competition, Information Costs, And Corporate Governance: The Use of Accounting Performance Measures in Proxy Contests, 10 J. Acct. \& Econ. 3 (1988).

162. For an outstanding example of this strategy, see Edmund A. Stephan, Highlights of the Montgomery Ward Proxy Contest from a Lawyer's Viewpoint, 11 Bus. Law. 86 (1955).

163. Bebchuk and Kahan, 78 Cal. L. Rev. at 1101 (cited in note 1) (stating that "[s]hareholder support for a contestant, and thus the degree to which disinterested shareholders would be inclined to vote for challengers rather than incumbents, depends primarily on shareholder perceptions of the relative quality of management")

164. Poor management that shows marked improvement will reduce their risk of ouster as shareholders learn of the improvement and stock prices rise, thereby reducing dissidents' opportunity to earn gains from improving management and lessening their incentives to launch a proxy contest. Id. at 1102.

165. See Black, 89 Mich. L. Rev. at 595-608 (cited in note 17), for an insightful review of the confiicts of interest faced by different imstitutions. See also Bebchuk and Kahan, $78 \mathrm{Cal}$. L. Rev. at 1084 n.55.

166. Proxy contests are "the most expensive, the most uncertain, and the least used" of the different methods of changing control of a corporation. Manne, $73 \mathrm{~J}$. Pol. Econ. at 114 (cited in note 129). See Frank H. Easterbrook and Daniel R. Fischel, The Proper Role of a Target's Management in Responding to a Tender Offer, 94 Harv. L. Rev. 1161, 1171 (1981); Ronald J. Gilson, $A$ Structural Approach to Corporations: The Case Against Defensive Tactics in Tender Offers, 33 Stan. L. Rev. 819, 843 (1981).

167. Bebchuk and Kahan, 78 Cal. L. Rev. at 1088. 
proxy contests, unfortunately, only proxy contests' effect on private costs and benefits. Nevertheless, if these studies showed that proxy contests have an unequivocally negative impact on shareholder wealth, they would strongly support using defensive tactics in proxy contests.

Existing studies focus on testing the hypothesis that proxy contests operate as a disciplinary force that keeps management's interests aligned with those of shareholders. ${ }^{168}$ This theory postulates that proxy contests will either replace poor managers with better ones, or give poor managers a loud wake-up call to improve their performance. ${ }^{169}$ The disciplinary hypothesis predicts that proxy contests will lead to increases in the target company's stock price and improved operating performance by proxy contest targets. Target companies also should exhibit poor operating performance prior to the contest. ${ }^{170}$ Existing empirical work largely confirms these predictions.

Target companies exhibit share price increases after the announcement of proxy contests, suggesting that proxy contests benefit shareholders by transferring corporate resources to more highly valued uses. ${ }^{171}$ Dodd and Warner find that these stock price increases occur

168. Early theoretical papers on these questions argued that proxy contests could not be effective monitoring mechanisms because incumbents had control of the proxy machinery, giving them a major advantage, and because successful dissidents would only capture a small portion of the gains from winning the contest. See Manne, 73 J. Pol. Econ. at 114-15 (cited in note 129). See also Pound, $20 \mathrm{~J}$. Fin. Econ. at 237 (cited in note 2) (arguing that proxy contests are relatively ineffective as a disciplinary device). Compare Dodd and Warner's description of proxy contests as a disciplinary mechanism "somewhere between a board dismissal of management and an outside takeover by another corporation." Peter Dodd and Jerold B. Warner, On Corporate Governance: A Study of Proxy Contests, 11 J. Fin. Econ. 401, 405 (1983).

169. In the case in which dissidents gain control of the company and cause a change of management the implication is clear. When dissidents fail to gain board seats, incumbent management's exposure to a threat of loss of employment, and the potential future threat from unhappy shareholders, suggests that managerial performance in those companies should improve as well.

170. Manne, $73 \mathrm{~J}$. Pol. Econ. at 14 (cited in note 129). The evidence about target companies' performance prior to the initiation of a proxy contest is mixed. Duvall and Austin found that on average targets of proxy contests had lower rates of return on equity than did their respective industries. Richard M. Duvall and Douglas V. Austin, Predicting the Results of Proxy Contests, 20 J. of Fin. 464, 464-67 (1965) (examining 64 proxy contests for control in the 1956-1960 period).

In examining long-term stock returns prior to the contest, neither Dodd and Warner nor DeAngelo observed significant evidence of abnormal returns. Dodd and Warner, $11 \mathrm{~J}$. Fin. Econ. at 406 (cited in note 168) and DeAngelo, $10 \mathrm{~J}$. Acct. \& Econ. at 4 (cited in note 161). DeAngelo did find that the accounting rate of return on equity for contest targets underperformed a benchmark based on the median return for a broad sample of companies for a period of three years prior to the contest. Id.

171. Dodd and Warner, $11 \mathrm{~J}$. Fin. Econ. at 401 (analyzing a sample of 96 proxy contests for board seats from 1962 to 1978 and finding an average abnormal stock price gain of nine percent from 60 trading days before contest announcement through the day after the outcome is announced); Harry DeAngelo and Linda DeAngelo, Proxy Contests and the Governance of Publicly Held Corporations, 23 J. Fin. Econ. 29 (1989) (finding similar results for a more recent sample of companies); J. Harold Mulherin and Annette B. Poulsen, Does a Proxy Have Real Moxie? The Performance Effects of Proxy Contests in the 1980s, Clemson University and University of Geor- 
even when the dissident is unsuccessful in obtaining representation on the board. ${ }^{172}$ DeAngelo and DeAngelo extend Dodd and Warner's analysis by showing that a substantial portion of the stock price gains from a proxy contest arise from the increased probability of the target being subsequently taken over. ${ }^{173}$ If dissidents win, frequently they will acquire the entire firm. Yet, in two-thirds of the contests, a win by the incumbents leads to a sale of the company, a liquidation, or a change of management within three years of the contest.

Proxy contests also generally lead to improvements in operating performance. ${ }^{174}$ Mulherin and Poulsen find significant stock price increases at the announcement of proxy contests and improvements in performance measured through changes in operating income, although the latter are generally insignificant. ${ }^{175}$ Borstadt and Zwirlein show that the observed gains in stock price are not dissipated over the three years following the contest. ${ }^{178}$

In contests in which the dissidents gain a majority of the board, however, researchers have observed declines in operating performance over a period of several years. ${ }^{177}$ Those firms that undergo dissident vic-

gia Working Paper 4-5 (August 1991) (confirming findings of significant shareholder wealth increases at proxy contest announcements). See also Easterbrook and Fischel, Economic Structure of Corporate Law at 71 (cited in note 129).

However, as Bebchuk and Kahan note, whether the stock price increases observed in a proxy contest result from management making a real performance improvement, or from management manipulating shareholder perceptions of performance by various subterfuges, is unclear ex ante. Bebchuk and Kahan, 78 Cal. L. Rev. at 1102-03 (cited in note 1). The former will increase social wealth, while the latter may be socially costly.

172. Dodd and Warner, 11 J. Fin. Econ. at 401 (cited in note 168) (finding that average abnormal stock price gains from 60 trading days before contest announcement through the day after the outcome is announced show average gains of $13 \%$ when the dissidents gain control and $8 \%$ when the incumbents retain control). However, they do not explain where this value increase comes from or why stock prices increase even when the incumbents win.

173. See DeAngelo and DeAngelo, 23 J. Fin. Econ. at 29 (cited in note 171).

174. Mulherin and Poulsen, Working Paper at 4-5 (cited in note 171).

175. Id. They claim that if proxy contests are an integral part of the market for corporate control, then society must judge the contests' success by whether they lead to improvements in shareholder wealth and corporate operating performance. See also David Ikenberry and Josef Lakonishok, Corporate Governance Through The Proxy Contest: Evidence and Implications, Rice University Working Paper No. 86 at 4 (1991) (finding improvements in operating performance measures when management nominees retain all board seats).

176. Borstadt and Zwirlein, Working Paper at 13 (cited in note 137). They find that proxy contests are a step "along the path to a change in control of the corporation even when the dissidents are unsuccessful in their attempt to obtain board representation during the challenge." Id. Proxy contests serve to alert the takeover market about potentially mismanaged firms, and then the market determines whether circumstances warrant a change of control. Dissident activity thus serves a disciplinary function, leading to permanent gains for shareholders. Id. at 20.

177. Id. at 17-20; Ikenberry and Lakonishok, Rice University Working Paper No. 86 at 4 (cited in note 175). Ikenberry and Lakonishok point out that an earnings decline during the first year after a dissident victory might be explained by the "earnings bath" effect reported by DeAngelo. Id. at 4. This phenomenon reflects dissidents' attempts to blame previous management for 
tories followed by a change of management (but not a sale to another firm) experience significant negative abnormal returns in the post-contest period. ${ }^{178}$ Notably, these companies account for only a small percentage of the proxy contests included in these studies.

One possible interpretation of these results is that not all control changes through the proxy contest mechanism are in the shareholders' best interests. Observers could interpret this downward drift in returns for dissident victories, and negative abnormal returns for companies when dissidents win seats on their board, as evidence that proxy contests are value destroying transactions. An alternative explanation is more consistent with the existing evidence. "Dissidents are more likely to win control of firms that are in very bad operating shape. ... [I]f the dissidents who take control of poor firms are unable to subsequently affect a sale of the firm, there is little hope of salvaging an already sinking ship."1z9 Ikenberry and Lakonishok's finding that companies in which dissidents won seats suffered from more severe performance problems on average than other companies supports this explanation. ${ }^{180}$ Nevertheless, these findings suggest that for firms in very bad shape, replacing existing inanageinent through a proxy contest may hasten their demise.

By comparison with proxy contests, the benefits that joint offers provide to target company shareholders are larger and unequivocally positive. ${ }^{181}$ Studies of the benefits of tender offers indicate the general size of benefits created by joint offers. ${ }^{182}$ Studies of target shareholder

poor decisions and then having the company take earnings hits in the period after the dissidents take power. It may also reflect security analysts' overly optimistic projections for companies taken over by dissidents. See Daniel W. Collins and Linda DeAngelo, Accounting Information and Corporate Governance: Market and Analyst Reactions to Earnings of Firms Engaged in Proxy Contests, 13 J. Acct. \& Econ. 213, 230-32 (1990).

178. Borstadt and Zwerlein, Working Paper at 17-20 (cited in note 137). See also Ikenberry and Lakonishok, Rice University Working Paper No. 86 (cited in note 175) (finding negative operating performance and abnormal stock price returns when dissidents won seats on a board, but finding this result to he less negative and imsignificant when a change of management occurred within 24 months of the proxy contest).

This conforms with the observed performance of acquiring firms after takeovers: they tend to exhibit downward drifts in stock prices. Borstadt and Zwerlein, Working Paper, at 27-28. See also Bernard S. Black, Bidder Overpayment in Takeovers, 41 Stan. L. Rev. 597, 609 n.40 (1989) (summarizing several studies on this issue).

179. Borstadt and Zwirlein, Working Paper at 19.

180. Id. at 17-19. Ikenberry and Lakonishok analyze data for five years prior to the initiation of dissident activity. They find that target companies exhibit significant negative abnormal returns prior to the announcement of the proxy contest. Id. at 3-4.

181. In recent years, legal scholars and finance theorists have extensively studied tender offers' benefit. A thorough review of this hiterature is beyond the scope of this paper. See Black, 41 Stan. L. Rev. at 601-13 (cited in note 178), for a thoughtful discussion of these studies.

182. See Gilson and Black, The Law and Finance of Corporate Acquisitions at 458 (cited in note 14). One potential difference between the two species of tender offers stems from the lengtby 
gains in tender offers uniformly show that bidders paid large premiums over existing market prices during the $1980 \mathrm{~s}$, on average fifty percent over existing prices. ${ }^{183}$ These premiums substantially enriched target company shareholders. ${ }^{184}$ Apparently, losses by the shareholders of acquirmg companies from successful tender offers did not offset these gains to target company shareholders: the estimated returns to acquiring company shareholders in the 1980s range from slightly negative to insignificantly different from zero. ${ }^{185}$ While not conclusively establishing that joint tender offer and proxy contests create wealth for society, these studies offer support for that position. ${ }^{186}$

Proxy contests have significant transactions costs that represent real social costs. An incumbent management's fight to win a proxy contest diverts time and attention away from operating the business. The fight may lower the morale of existing personnel and may increase em-

time period required to complete a proxy contest. Id. at $458-459$. This delay gives the target ample time to conduct a search for an alternative bidder. This search may affect the distribution of gains between the bidder and target. It may also increase the likelihood of an auction, an outcome that will affect the bids that the target receives. Id. at 458-59. Bidders who expect no operating synergies with the target would anticipate that the target's value to them will parallel that expected by other bidders. The increased possibility of an auction will discourage this type of bidder. Synergistic bidders, who expect some unique form of synergistic gain from operating the target, will still beheve that they can recognize greater value from the target company than other bidders and having to participate in an auction should upset them less. Id. As a rough approximation though, the benefits and costs realized from a joint tender offer and proxy contest should correspond to those generated by an ordinary tender offer.

183. See Gregg A. Jarrell, James A. Brickley and Jeffry M. Netter, The Market For Corporate Control: The Empirical Evidence Since 1980, 2 J. Econ. Persp. 49 (Winter 1988); Black, 41 Stan. L. Rev. at 601-05 (cited in note 178).

184. Jensen calculates that target shareholders realized roughly $\$ 346$ billion in overall gains from takeovers and restructurings in the ten-year period 1977-86, while Black and Grundfest estimate that the gains to target shareholders from takeovers between 1981 and 1986 were $\$ 162$ billion. Michael C. Jensen, Takeovers: Their Causes and Consequences, 2 J. Econ. Persp. 21 (Winter 1988); Bernard S. Black and Joseph Grundfest, Shareholder Gains From Takeovers and Restructurings Between 1981 and 1986: \$162 Billion Is A Lot Of Money, 1 J. Applied Corp. Fin. 5 (Spring 1988).

185. Black, 41 Stan. L. Rev. at 602 (cited in note 178); Jarrell, Brickley, and Netter, 2 J. Econ. Persp. at 53 (cited in note 183).

186. Scholars heavily debate the source of these gains. One group of scholars believes that the premiums paid in takeovers reflect real efficiency gains from productive entrepreneurial activities that improve the control and management of assets and help to move assets to more productive uses. Jarrell, Brickley, and Netter, 2 J. Econ. Persp. at 6-8 (cited in note 183). Other economists studying accounting data reject this claim because these data fail to show significant improveinents in the target's performance. Black, 41 Stan. L. Rev. at 605-06 (cited in note 178). These studies suggest that the gains to target shareholders simply inay represent wealth transfers from others, such as the target's creditors or employees. See generally John C. Coffee, Jr., Regulating the Market for Corporate Control: A Critical Assessment of the Tender Offer's Role in Corporate Governance, 84 Colum. L. Rev. 1145 (1984). Compare Black, 41 Stan. L. Rev. at $611-12$ (summarizing empirical studies that show that wealth transfers explain at most a small fraction of these transfers). An intermediate thesis posits that some of these gains represent efficiency gains, hut that in inany cases target shareholders gain because bidders overpay for the target. Id. at 601 . 
ployee turnover. The contestants can incur substantial costs in bringing and defending a proxy contest. ${ }^{187}$ Furthermore, proxy contest defensive tactics may be costly to implement and wasteful in themselves. ${ }^{188}$ When insiders dominate a target company's board, Rights Plans are particularly costly to that company's shareholders. ${ }^{189}$ The corporation, and ultimately its shareholders, bear these costs.

In short, while the existing empirical data strongly suggest that proxy contests increase wealth (except in a small percentage of cases), no research has compared all of the relevant costs and benefits. Proxy contests lead to increases in stock prices and improved operating performance for most target companies. Wealth increases are especially pronounced with joint offers. However, for very poorly performing companies, operating performance deteriorates if dissidents win control of the board and fail to sell or to restructure the company. In addition, conducting a proxy contest entails significant costs. For these reasons, the most that can be said is that the use of defensive tactics, such as Rights Plans, in proxy contests cannot be justified as wealth increasing based on our current state of knowledge.

\section{Argument 4: Joint Offers Pose the Same Threats as Tender Offers}

The fourth argument in favor of managerial defensive tactics in proxy contests focuses on a special subset of proxy contests: joint offers. As incumbent management has obtained the weapons to defeat naked tender offers, joint offers have become increasingly important to the market for corporate control. ${ }^{190}$ In responding to this new threat to their control of the target corporation, managers have argued that joint offers are just thinly disguised tender offers. Thus, the argument runs,

187. For example, in Armstrong World Industries' proxy contest with the Belzburg family's First City Financial Corporation, Armstrong estimated its total expenditures relating to the incumbents' solicitation of proxies at approximately $\$ 2$ million. Proxy Statement of Armstrong World Industries, Westlaw, SEC On Line at ${ }^{* 20}$ (March 9, 1990). First City Fimancial almost certainly incurred similar costs.

188. Bebchuk and Kahan, $78 \mathrm{Cal}$. L. Rev. at 1104 (cited in note 1). These authors give the example of management having the company pay additional (unnecessary) charges to a bank that holds the company's stock in order to influence the bank's voting behavior in a proxy contest. Id. For a Rights Plan, these costs would include the legal fees associated with creatimg or amending the plan, any litigation costs incurred in fighting over its scope or validity, and the cost of creating or redeeming the rights themselves.

189. Companies that do not have a majority of independent directors on their boards realize stock price declines when they implement Riglits Plans. See Black, 39 U.C.L.A. L. Rev. at 901, 913 (cited in note 17).

190. See notes 13-21 and accompanying text for further discussion. 
tender offer defensive tactics should be available for use in responding to joint offers. ${ }^{191}$

Legal scholars have engaged in a lively debate over the merits of managerial defensive tactics in response to hostile tender offers. ${ }^{192}$ While a full discussion of this literature is beyond the scope of this Article, the main arguments made about the use of tender offer defensive tactics apply to their use in joint offers and therefore must be discussed briefly.

Early commentators argued that tender offers were an important mechanism for monitoring managerial performance. ${ }^{193}$ Defensive tactics should be sharply limited, ${ }^{104}$ or even eliminated, ${ }^{185}$ because they impeded tender offers that paid shareholders a premium for their shares in the target company. ${ }^{198}$ Scholars hotly disputed the propriety of allowing management to use defensive tactics to search out competing bids: Easterbrook and Fischel argued that discouraging competing bids would maximize shareholder wealth because it increased the probability that a tender offer would be made, ${ }^{197}$ while Gilson and Bebchuk sup-

191. When an acquirer makes a tender offer, incumbents have argued that the directors have a duty to protect shareholders from any harm that these acquisitions may pose to them. See generally Apple Bancorp II C.A. No. 11510, 1990 Del. Ch. LEXIS 121 (Aug. 9, 1990). Thus, if the directors believe shareholders need a Rigbts Plan for protection against destructive tender offers, but this plan has "incidental" adverse effects on proxy contests, tbe courts could ignore these negative effects to protect shareholders from a greater harm. Moran, 490 A.2d at 1080 . This argument is subject to the critical qualification, however, that the shareholders must retain the power "to turn the board out" if the board's actions displease them. Unocal, 493 A.2d at 959. Dissatisfied shareholders only retain the power to "turn the board out" if they can win a proxy contest or close a tender offer.

192. See generally Easterbrook and Fischel, 94 Harv. L. Rev. at 1161 (cited in note 166); Easterbrook and Fischel, 35 Stan. L. Rev. at 1 (cited in note 143); Gilson, 33 Stan. L. Rev. at 819 (cited in note 166); Ronald J. Gilson, Seeking Competitive Bids Versus Pure Passivity in Tender Offer Defense, 35 Stan. L. Rev. 51 (1982); Lucian A. Bebchuk, The Case For Facilitating Competing Tender Offers, 95 Harv. L. Rev. 1028 (1982); Lucian A. Bebchuk, The Case for Facilitating Competing Tender Offers: A Reply and Extension, 35 Stan. L. Rev. 23 (1982); Coffee, Jr., 84 Colum. L. Rev. at 1145 (cited in note 17); David W. Leebron, Games Corporations Play: A Theory of Tender Offers, 61 N.Y.U. L. Rev. 153 (1986); David D. Haddock, Jonathan R. Macey and Fred S. McChesney, Property Rights in Assets and Resistance to Tender Offers, 73 Va. L. Rev. 701 (1987). 166).

193. See, for example, Easterbrook and Fischel, 94 Harv. L. Rev. at 1173-74 (cited in note

194. See, for example, Bebchuk, 35 Stan. L. Rev. at 24-25, 34-35; Gilson, 35 Stan. L. Rev. at 62-66.

195. See, for example, Easterbrook and Fischel, 94 Harv. L. Rev. at 1164; 1194-1204 (cited in note 166$)$.

196. See Bebchuk, 95 Harv. L. Rev. at 1034 (cited in note 192).

197. Easterbrook and Fischel, 94 Harv. L. Rev. at 1177-82 (cited in note 166). The crux of tbeir position is that while permitting management to solicit competing bids may maximize shareholder welfare after a dissident makes an offer, from an ex ante viewpoint, such a rule would decrease the probability tbat a dissident will make a bid by driving up the premium that it must pay in the tender offer. Id. 
ported facilitating competing bids to raise the premium that target shareholders received in a tender offer. ${ }^{198}$ Finally, the two sides disagreed over the impact of managerial defensive tactics on bidders' incentives to search for targets. ${ }^{199}$

Later commentators have adopted stronger positions in favor of management defensive tactics. For example, Haddock, Macey, and McChesney argue that managers need stronger bargaining positions to negotiate good deals for their shareholders. Denying managers the ability to resist tender offers leads to the bidder obtaining all of the value created by the acquisition. ${ }^{200}$ This claim assumes that shareholders' gains from management's improved bargaining more than offset their potential losses from management's entrenching itself under the pretense of forceful bargaining.

Another theory claims that managers need discretion to resist hostile acquisitions to prevent shareholders from opportunistically reneging on implicit contractual agreements. ${ }^{201}$ This theory views tender offers as a means by which shareholders can deprive managers of the benefits of agreements they have made with the board of directors and argues that defensive tactics are a manager's best method of preventing such action. ${ }^{202}$ Once again, however, the validity of this argument depends crucially on the assumption that managers will not act opportunistically and abuse their discretion to deploy defensive tactics against a tender offer that benefit themselves at the expense of target shareholders.

These authors also appear to believe that target managers who engage in defensive tactics rarely do so in the best interests of their shareholders. See Easterbrook and Fischel, 35 Stan. L. Rev. at $I$ (cited in note 143).

198. Bebchuk, 95 Harv. L. Rev. at 1050-56 (cited in note 192); Bebchuk, 35 Stan. L. Rev. at 45-50; Gilson, 33 Stan. L. Rev. at 865-75 (cited in note 166).

199. Easterbrook and Fischel objected to an auctioneering rule because they believed that it would decrease search for potential targets and consequently decrease the number of offers. Easterbrook and Fischel, 94 Harv. L. Rev. at 1177-78 (cited in note 166). Bebchuk and Gilson acknowledged that bidding contests could decrease the amount of bidder search. They argued, however, that an auction rule still would result in a significant amount of search and that searchers could hedge against the risk of losing their sunk costs by buying shares in the target company. Gilson, 33 Stan. L. Rev. at 870-75 (cited in note 166); Bebchuk, 35 Stan. L. Rev. at 30-33 (cited in note 192).

200. Haddock, Macey and McChesney 73 Va. L. Rev. at 709 (cited in note 192); Leebron, 61 N.Y.U. L. Rev. at 153 (cited in note 192).

201. A successful tender offeror refusing to pay the inanagers of the target firm performance bonuses that the outgoing board of directors had informally promised would provide one example of this type of opportunistic behavior.

202. See Charles R. Knoeber, Golden Parachutes, Shark Repellants, and Hostile Takeovers, 76 Am. Econ. Rev. 155 (1986); Haddock, Macey and McChesney, 73 Va. L. Rev. at 712-17 (cited in note 192). 
Each of these arguments for and against management defensive tactics to defeat hostile tender offers applies to joint offers. If Easterbrook and Fischel's passivity thesis is accepted, no room remains for management defensive tactics against joint offers. On the other hand, if Bebchuk and Gilson's view is accepted, then courts should allow managers to facilitate bidding contests in joint offers by using certain defensive tactics. Similarly, the courts could apply Haddock, Macey, and McChesney's arguments in favor of management defensive tactics in the joint offer context.

However, one crucial additional qualification must be made to these arguments in the joint offer context: shareholders must have an opportunity to elect the representatives of their choice if directors' control over the corporation is to be legitimated. If the courts permit managers to block tender offers, then annual elections of directors are the shareholders' only remaining method of putting their chosen representatives into power in the face of management opposition. If shareholders have no means of removing unwanted management from power, the temptations for managers to engage in self-interested behavior could be irresistible. $^{203}$

Preserving shareholders' ability to control the management of their property requires a more careful scrutiny of management defensive tactics in joint offers than in naked tender offers. Not only will the courts need to determine whether managers are acting in shareholders' best interests in resisting an acquisition, but they also will have to balance the impact of defensive tactics on shareholders' basic right to determine who manages their property. An additional level of scrutiny must be imposed before managers should be permitted to act in a way that might absolutely preclude their removal.

The strength of management's claim that it is acting in shareholders' best interests will depend on the particular defensive tactic that it deploys and the situation in which the tactic is used. For example, the courts might allow the use of a mild defensive tactic, such as a short delay in an annual meeting date, in the face of a joint offer when the incumbents' claim is that the deployment of a defensive tactic allows them to search for alternative transactions to maximize shareholder value. $^{204}$ This delay must be only temporary, though, if the law is to protect the shareholders' right to remove management. On the other hand, when the dissident group seeks only a minority of the seats on the board, and has no history of making control acquisitions (or faces

203. For an interesting article arguing that shareholder voting rights are not so fundamental, see Michael P. Dooley, Two Models of Corporate Governance, 47 Bus. Law. 461 (1992).

204. Apple Bancorp I, 579 A.2d 1115, 1115 (Del. Ch. 1990). 
other legal obstacles to seeking control), little justification exists for permitting the deployment of defensive tactics, such as a Rights Plan, against their efforts. ${ }^{205}$

\section{Summary}

The weakness of the arguments in favor of defensive tactics in proxy contests points to the conclusion that few legitimate threats to the corporation justify management's use of a Rights Plan agamst dissident sohicitations. When valid reasons exist for allowing management to use Rights Plans, such as those put forward with respect to tender offers, the case for using Rights Plans against joint offers is weaker than with tender offers because these defensive measures may completely preclude shareholders from determining who will manage their investments.

The courts will need to balance legitimate threats to the corporation against the shareholders' right to control their investment in deciding when they will permit Rights Plans to be used in proxy contests. In conducting their balancing, the courts should have a strong presumption in favor of protecting shareholders' ability to choose the best candidates in an unfettered election. The directors' claim that they know what is best for the shareholders rings particularly hollow in a contested election where incumbents have a vested interest in being reelected, and the shareholders have no other means of removing them from power. ${ }^{208}$

Unfortunately, the courts' treatment of Rights Plans and their application to dissident proxy solicitations have given managers too much discretion. As discussed earlier, Rights Plans have a variety of negative impacts on dissidents' election campaigns. Yet the courts have largely downplayed these effects. Particularly when dissidents have commenced a joint offer, the courts have failed to protect shareholders' ability to remove unwanted managers and instead have allowed the incumbents to manipulate unfairly the outcome of corporate elections. Part IV looks at how the existing judicial tests for defensive tactics in proxy contests could be improved.

205. Gilson and Kraakman, 43 Stan. L. Rev. at 903-04 n.145 (cited in note 17).

206. See, for example, Bebchuk and Kahan, 78 Cal. L. Rev. at 1077 (cited in note 1): Incumbents tend to have self-interested motives for maintaining control: they want to retain the private benefits (such as high salaries and perks) that are associated with exercising control. Their interest in preserving their own control might exceed any interest they have in letting better managers run the company. Id. 


\section{When Is a Rights Plan Right in a Proxy Contest?}

In evaluating the use of Rights Plans in proxy contests, the courts have, under various rubrics, ${ }^{207}$ balanced the incumbents' interest in protecting the corporation and its shareholders from harm and a Rights Plan's negative effect on a dissident's chances of winning a proxy contest. $^{208}$ The courts have placed the burden on incumbents to justify defensive tactics because of their potential for misuse as entrenchment devices. However, to date, judicial review has been highly deferential to the incumbents' use of Rights Plans, despite their adverse impact on a dissident's chances of winning a proxy contest. While a balancing test such as that developed in Unocal is appropriate in evaluating these competing interests, judges must be careful in applying it to examine critically incumbents' use of Rights Plans to impede free elections.

For a Unocal-type test to be effective, the courts will need guidance in discriminating between different types of defensive tactics. In particular, they need to know what threats constitute legitimate bases for defensive tactics in a proxy contest. Once these threats have been delineated, the courts will need to judge whether the incumbents' defensive tactics are an appropriate response to the threat. In making this decision, the courts must measure the impact of defensive tactics on a dissident's chances of winning a proxy contest. Finally, as with other defensive tactics, management's inherent interest in retaining its office should lead the courts to require them to shoulder the burden of persuasion that the defensive tactics' adverse impact on a dissident's proxy solicitation is justifiable. The court will need to know how heavy they should make incumbents' burden of persuasion. This Part develops this framework to examine Rights Plans' application in proxy contests and joint offers critically.

\section{A. What Threats Justify Deploying Rights Plans in Proxy Contests?}

Proxy contests pose four "threats" to shareholders' interests ${ }^{200}$ that might justify incumbents' deployment of Rights Plans against dissident

207. See note 88 for further discussion of the equivalence of the various tests that the courts have apphed to Rights Plans that adversely affect a dissident's chances of winning a proxy contest.

208. In this balancing test, the courts must use their "imdependent judgment in balancing the reasonable skepticism of shareholders (which considered alone would suggest prohibiting preclusive [defensive] tactics) against the presumptive expertise of managers (which considered alone would suggest blanket business judgment protection of preclusive [defensive] tactics.)" Gilson and Kraakman, 44 Bus. Law. at 266 (cited in note 51).

209. After Paramount, it could be argued that the courts should consider "threats" to the corporation's and other stakeholders' interests in determining whether to permit defensive tactics in a proxy contest. Compare Apple Bancorp I 579 A.2d at 1123 n.9. If this were true, then the 
election campaigns: information imperfections; self-interested small shareholder victories; potential wealth decreasing effects of proxy contests; and hostile tender offers. The first argument, that shareholders have inadequate information and lack incentives to gather more, points toward encouraging shareholders to become better informed and to removing any obstacles that stand in the way of informing them. Rights Plans, which can obstruct information flows between shareholders, would only exacerbate this information problem and should not be permitted on this basis.

The claim that proxy contests should be impeded because victorious small shareholders will engage in self-interested diversions of corporate resources, the second potential justification for using Rights Plans against proxy contests, ignores the dissidents' need to persuade other wealth-maximizing shareholders of the merits of their efforts. Given the difficulty of convincing disinterested institutions to vote against management, and the incumbents' substantial advantages stemming from their control of the proxy mechanism, little need exists for deploying Rights Plans to impede small shareholders' efforts to persuade other shareholders to join them in unseating management.

The claim that proxy contests are inefficient and decrease social wealth does not support the use of Rights Plans in proxy contests. The available data, while not conclusive, suggest the opposite conclusion, that is, that proxy contests increase target company shareholders' wealth. Furthermore, Rights Plans are costly to create and can depress the value of shareholders' investments. ${ }^{210}$

The fourth category of justifications, that Rights Plans serve to deter hostile tender offers, is the most frequently advanced by the courts in support of the use of Rights Plans in proxy contests. ${ }^{211}$ The courts already have issued some guidelines concerning the scope of this threat. At the one end of the spectrum, Moran held that management could use Rights Plans to stop dissidents from accumulating more than twenty percent of the target's stock in a proxy contest. ${ }^{212}$ Without this restriction, the court found, Rights Plans would be an ineffective defense against tender offers. At the other end of the spectrum, the courts

incumbent board could maintain itself in power indefinitely by creating a long-term business plan and claiming tbat a dissident's election campaign constituted a threat to the plan and to the corporation's and stakeholders' long-term best interests. Paramount's reaffirmation that the shareholders bave the ultimate right to vote out the incumbent directors strongly indicates that the courts would not sanction this subterfuge.

210. See notes 187-89 and accompanying text for a discussion of this point.

211. Of course, if one concludes that the courts should not permit management to use defensive tactics in response to a tender offer, as Easterbrook and Fischel argue, then no room exists for defensive tactics in proxy contests based on these justifications.

212. Moran, 500 A.2d at 1355. 
consistently have held that tender offer defensive tactics must allow shareholders the opportunity to vote management out of office ${ }^{213}$ and that the threat of losing an election does not justify the use of defensive tactics in a proxy contest. ${ }^{214}$

Proponents have suggested three distinct rationales for using Rights Plans against tender offers that might vindicate incumbents' use of Rights Plans against proxy contests. The first, that management needs a Rights Plan to gain enough leverage to negotiate with a potential acquirer, or to shop the firm to other bidders, ${ }^{215}$ has some validity for proxy contests and joint offers. This is especially true when the dissidents' platform is that they intend to sell off or restructure the company. If management can bring in a third-party bidder at a higher price, or induce the dissident to promise a more attractive subsequent acquisition, then the target company shareholders will benefit from giving them the opportunity to do so. ${ }^{216}$

The second rationale is that Rights Plans can insulate a target company's shareholders from structurally coercive tender offers that treat tendering and nontendering shareholders differently. ${ }^{217}$ Structural coercion occurs when, as in a front-end-loaded, two-tiered tender offer, the bid's unequal treatment of shareholders forces shareholders to accept the offer to avoid the adverse consequences of refusal. With proxy contests, this threat seems attenuated. If a dissident proposed to treat shareholders differently after being elected, adversely impacted shareholders would vote against the dissident slate, the opposite result than with a coercive tender offer.

The third justification for using Rights Plans to stop tender offers is the risk of substantive coercion, or that shareholders might accept an inadequate tender offer because they do not believe management's accurate representations about the long-term (higher) value of the target company. ${ }^{218}$ The Rights Plan acts to preserve the target company's independence and to permit existing management to raise the value of its shares above the level proposed by the hostile bidder. ${ }^{219}$ The crux of

213. Unocal, 493 A.2d at 949 .

214. See, for example, Sutton, 1991 Del. Ch. LEXIS 85 at *1.

215. Gilson and Kraakman, 44 Bus. Law. at 261 (cited in note 51). When shareholders are dispersed and incapable of a coordinated response to a tender offer, they may need management to serve as their negotiator to gaim a larger share of the gains from the transaction. Id.

216. The knowledge that incamhents will be free to engage in such a search may discourage some potential rival candidates from deciding to launch a proxy solicitation. See notes 193-99 and accompanying text for a discussion of this problem in the tender offer literature.

217. See Gilson and Kraakman, 44 Bus. Law. at 261. They define structural coercion as "the risk that disparate treatment of non-tendering shareholders might distort shareholders' tender decisions." Id. at 267.

218. Id. at 267.

219. Id. at 262. 
this claim is that management can truthfully make the claim that they will improve performance but that shareholders do not believe them. ${ }^{220}$

For proxy contests, substantive coercion amounts to a claim that shareholders will mistakenly vote for the dissidents even though management correctly tells its shareholders that it can improve the company's performance if given more time. ${ }^{221}$ Again, this claim seems weaker than with tender offers. Management has ample opportunity and incentives to inform shareholders of its plans and expectations about the future value of the company and to criticize the dissidents' proposals. Management can even copy the dissidents' platform and credibly argue that they are better able to execute it than any outsiders. Furthermore, shareholders have less incentive to rush to embrace the dissidents' election platform than they do to sell their shares at a premium price in a tender offer. They will be more critical of untried plans to run the company than of the prospect of an immediate cash payout.

However, empirical studies have found disturbmg evidence that when dissidents succeed in winning proxy contests at poorly performing companies, and no subsequent restructuring or sale of the company takes place, the performance of the company declines markedly. ${ }^{222}$ This evidence could support the claim that at least in some cases, shareholders do vote for the wrong candidates and that they would be better off if management had used preclusive defensive tactics, such as a Rights Plan that prohibited dissidents from receiving revocable proxies. ${ }^{223}$ The courts cannot rule out substantive coercion as a possible threat to shareholders. ${ }^{224}$

\section{B. Analyzing the Impact of Rights Plans on Dissident Election Campaigns: Common Sense and Statistics}

Once the incumbents have articulated the threats posed by the dissidents' election campaign, the court must weigh the use of the Rights Plan against its impact on a dissident's abihty to win a proxy contest to determine if the defensive response to this threat is proportionate. The

220. Id. A legitimate claim of substantive coercion requires the incumbents to sbow how and when they can improve the company's performance. Id. at 268.

221. This is similar to Bebchuk and Kahan's argument that information problems can result in inefficient dissidents winning proxy contests. See Part III.C.1. for further discussion of this point.

222. See notes 171-79 and accompanying text for a discussion of these studies.

223. See Sutton, 1991 Del. Ch. LEXIS 85 at *1.

224. In passing on a claim of substantive coercion, a court should consider management's expertise, the specificity and completeness of its plans, the firm's performance history, expert testimony, the target board's dehberations about the plans, and any prior history about management's claims of substantive coercion in other takeover attempts. Gilson and Kraakman, 44 Bus. Law. at 271 (cited in note 51). 
answer to this question requires an analysis of what impact the Rights Plan has on a dissident's chances of winning a contest. If Rights Plans have little or no impact, then they could be applied without concern. On the other hand, if Rights Plans have a significant negative effect on dissident success, then the courts will need to look more closely at incumbents' justifications for using them.

How can courts determine the impact of a proposed defensive tactic on a dissident's chances of winning a proxy contest? A judge should consider several different types of evidence, ranging from common sense and simple statistics to sophisticated economic analyses. ${ }^{225}$ The impact of Rights Plans on dissident proxy solicitations illustrates how these several forms of analysis would fit together.

At the simplest level, summary statistics will give a judge a good indication of what effects Rights Plans (or other defensive tactics) are likely to have on the outcome of proxy contests. For example, when a Rights Plans has a trigger level that is below the level of dissidents' average holdings in proxy contests, common sense indicates that this will have a negative impact on a dissident's chances of winning a proxy contest. ${ }^{228}$

A court could ask the parties to conduct a study of the average size of dissident stockholdings. Alternatively, the court could refer to existing studies on this question. Good information exists about the average level of dissident stockholdings in proxy contests. Pound's study of 100 proxy contests (including issue contests) during the period of 1981-

225. The courts' ability to recognize and properly use extralegal information, such as statistical studies, in deciding cases has been the subject of much legal commentary. See, for example, Michael J. Saks, Judicial Attention to the Way the World Works, 75 Iowa L. Rev. 1011 (1990); J. Alexander Tanford, Law Reform by Courts, Legislatures, and Commissions, 25 L. \& Soc. Rev. 155 (1991); Peggy Davis, There is a Book Out: An Analysis of Judicial Absorption of Legislative Facts, 100 Harv. L. Rev. 1539 (1987); John Monahan and Laurens Walker, Social Authority: Obtaining, Evaluating, and Establishing Social Science in Law, 134 U. Pa. L. Rev. 477 (1986); Laurens Walker and John Monahan, Social Frameworks: A New Use of Social Science in Law, 73 Va. L. Rev. 559 (1987); Laurens Walker and John Monahan, Social Facts: Scientific Methodology as Legal Precedent, 76 Cal. L. Rev. 877 (1988).

The use of special studies or other evidence introduced by the parties (or the court's own expert) to determine a particular fact at issue in the case, in this instance the impact of a particular Rights Plan on a particular dissident's proxy solicitation campaign, is an adjudicative or social fact use of data. See Saks, 75 Iowa L. Rev. at 1025. If, however, the court chooses to rely upon general knowledge, such as studies done by third parties on the impact of Rights Plans on proxy contests, to make particular determinations in a case, this is a social framework use of the information. Id. at 1020. The issue becomes what do these studies tell the court about the particular application of the particular Rights Plan at issue in the case. The appellate courts generally subject social frameworks, and the methodologies of case-specific studies used to find social facts, to de novo review, while subjecting adjudicative facts to the clearly erroneous standard. Id. at 1030 .

226. In doing their jobs, judges must take account of the way that the world works. Common sense, or knowledge that seems so apparently true that it seems intuitively obvious, is one of a judge's sources of information. Id. at 1015. 
1985 found that dissidents' average stockholdings were about twelve percent of the total equity of the target company. ${ }^{227}$ Thomas and Martin's more recent study of eighty-nine control contests from 1985-1991 found that average dissident stockholdings were $11.4 \% .^{228}$

The implication of these studies is that a Rights Plan with a trigger level below ten percent (or even fifteen percent) would force many dissidents to hold less stock than they would otherwise have chosen to liold. Decreased levels of dissident stock ownership will require dissidents to find more support from other stockholders. This will translate into a more difficult struggle to win a proxy contest. Pound's research confirms that lower levels of dissident stock ownership decrease the likehliood that a dissident will win a proxy contest. ${ }^{228}$

The upshot of this crude analysis indicates that tle courts should prohibit Rights Plans witl low (ten to fifteen percent) trigger levels. Several courts have enjoined Riglits Plans with low trigger levels on the grounds that they would adversely affect dissident election campaigns, albeit without explicitly stating how they reached this conclusion. ${ }^{230}$

To supplement this reliance on simple statistics, and to look at more subtle effects of some defensive tactics, the courts will need to rely on more sophisticated statistical studies. More explicit and rigorous treatment of statistical evidence would improve the courts' analysis of the effects of Rights Plans on proxy contests.

Traditionally, the courts have relied on the parties to introduce evidence on such questions. ${ }^{231}$ However, in several key cases, notably Moran and Apple Bancorp II, this has left the court witlout an adequate record when the parties failed to introduce important evidence.

Moran illustrates how an incomplete, partisan record can result in a court reaching dubious conclusions about the impact of Rights Plans on proxy contests. In Moran, the Court evaluated a Rights Plan's impact on a dissident's chances of winning a proxy contest by relying solely on a study done by Georgeson $\&$ Co., a professional proxy solicitation firm, and the testimony of one of its officers. ${ }^{232}$ The Georgeson

227. Pound, 20 J. Fin. Econ. at 252 (cited in note 2).

228. Thomas and Martin, Working Paper at 29 (cited in note 137).

229. Pound, 20 J. Fin. Econ. at 261.

230. See, for example, Dynamics Corp. of America v. CTS Corp., 794 F.2d 250 (7th Cir. 1986). See also Avon, 738 F. Supp. at 686 (discussing the New York statute authorizing Rights Plans with trigger levels of $20 \%$ and higher).

231. With respect to Rights Plans, this evidence might include sophisticated statistical analyses like Pound's study discussed below. Alternatively, the courts could admit the testimony of proxy solicitors.

232. In its study, Georgeson assembled data on 96 of the estimated 122 proxy contests that took place from 1981-1984. Georgeson \& Co., Inc., Report on Proxy Contests: January 1, 1981September 28, 1984 (the "Georgeson 1984 Report"). 
witness stated that the Georgeson 1984 Report showed there was "no correlation between the size of an insurgent's holdings and the likelihood of success" by a dissident in a proxy contest. ${ }^{233}$ Relying on this document, the Court found that the likelihood the Rights Plan would frustrate shareholders' efforts to conduct a proxy solicitation was "highly conjectural."234

A closer examination of the Georgeson 1984 Report shows its significance was much less clear. The Report contains no rigorous statistical analysis of the data presented. The Report calculates only a few descriptive statistics and these simply show that some dissident groups holding less than twenty percent of a target company's stock have won proxy contests. ${ }^{235}$ To reach an informed decision, the Court needed a more complete record on which to base its analysis.

At the time of the Moran decision, no empirical work had been done to estimate the impact of Rights Plans on the outcome of proxy contests. Since that time, two studies have been conducted that subsequent courts could rely on in making determinations about the effects of Rights Plans on proxy contests. Pound's study of 100 proxy contests (including issue contests) in the period 1981-1985 examined the impact of a twenty percent trigger level on the likelihood of a dissident winning a proxy contest. ${ }^{236}$ Pound found that successful dissidents hold on average about twelve percent of a target company's shares. He concluded that this evidence "suggests that a number of recent takeover defense innovations, which set a threshold level for dissident ownership at twenty percent, do not preclude a successful proxy fight". ${ }^{237}$ At the very least, however, Pound's study indicates that a Rights Plan with a trigger level of ten percent, or even fifteen percent, would adversely impact dissidents' chances of winning a proxy contest.

233. Instead, he claimed that "the merit of an insurgent's cause rather than the size of his holdings [is] the key to success." Moran, 490 A.2d at 1079.

234. Id. at 1080 .

235. Georgeson 1984 Report $\S 4$, at 1 (cited in note 232). The Report limited its analysis to a single page summary of two statistical comparisons. The first comparison showed that the percentage of contests won by shareholders holding more than $20 \%$ of a target coinpany's stock was approximately the same as the percentage of contests won by shareholders holding less than $20 \%$ of the target company's stock. The second statistical comparison stated that "dissidents controlling less than $10 \%$ of the voting power won approximately $36 \%$ of the time, while dissidents controlling $20 \%$ of the voting power won only $27 \%$ of the time." Id.

These conclusions ignore the impact of voting power on settlements in proxy contests. If contests ending in settlements are considered, then the data show that dissidents with more than $20 \%$ of the stock are $50 \%$ more likely to win a proxy contest or force a settlement than dissidents witl less than $20 \%$ of the stock. Ronald E. Schrager, Corporate Conficts: Proxy Fights in the 1980s 48 (Investor Responsibility Research Center, Inc., 1986).

236. Pound, $20 \mathrm{~J}$. Fin. Econ. at 237 (cited in note 2)

237. Id. at 261. 
Thomas and Martin's more recent study uses data on eighty-nine proxy contests from 1985-1991 and finds that the presence of a Rights Plan signals dissident stockholders that a company is a potential candidate for a proxy contest. ${ }^{238}$ More significantly, Thomas and Martin find that Rights Plan trigger levels below twenty percent have a significant negative effect on dissident stock ownership. ${ }^{239}$

These studies strongly suggest that while the Moran court correctly recognized that a flip-over Rights Plan with a twenty percent trigger would have little effect on most dissidents' proxy solicitation efforts, other courts should not uncritically adopt this conclusion for other types of Rights Plans. Unfortunately, some later decisions cite Moran as having definitively established that all Rights Plans have an immaterial effect on dissidents' chances of winning a proxy contest. ${ }^{240}$

To the extent that the courts are unable to find adequate statistical studies on which to base informed determinations about the effects of defensive tactics on proxy contests, and the parties fail (as they have in most cases) to provide an adequate record on which to base this judgment, then the courts should consider appointing their own expert to evaluate the impact of the defensive tactic. ${ }^{211}$ The federal courts have made such appointments under the authority granted them by Federal Rule of Evidence $706 .{ }^{242}$ A recent study by the Federal Judicial Center estimates that twenty percent of federal district court judges have appointed their own experts. ${ }^{243}$ The Delaware Supreme Court recently has proposed that trial courts consider using court-appointed expert witnesses to provide them with a more objective analysis. ${ }^{244}$

The court could appoint an expert based on nominations from the parties or select one on its own. The court would need to appoint these experts sufficiently in advance of trial to allow a hearing on the appointment, to determine the duties of the expert, and to provide the expert with sufficient time to prepare an analysis for the court and the parties. The expert should advise the parties of all findings and submit to depositions. ${ }^{245}$ At trial, either party may call the witness, or the court

238. Thomas and Martin, Working Paper at 25 (cited in note 137).

239. Id. at 25-26. One imphication of these results is that the courts should generally strike down incumbents' attempts to amend existing Rights Plans to lower their trigger levels below twenty percent.

240. See, for example, Apple Bancorp II 1990 Del. Ch. LEXIS 121 at *43.

241. See Saks, 75 Iowa L. Rev. at 1028 (cited in note 225).

242. Fed. R. Evid. 706 advisory committee's note. See also United States v. Green, 544 F.2d 138, 145 (3d Cir. 1976) (noting "the inherent power of a trial judge to appoint an expert of his own choosing is clear").

243. Jonathan M. Moses, Judges Call In Their Own Experts To Aid Court On Technical Issues, Wall St. J. B8, col. 1 (July 2, 1992).

244. In re Appraisal of Shell Oil Company, 607 A.2d 1213, 1222 (Del. 1992).

245. Id. at *30. 
would call the witness if necessary. The expert should be paid by the parties in the manner in which the court determines is appropriate. ${ }^{246}$

Once the court has determined the effect of the particular Rights Plan on dissidents' chances of winning a proxy contest, it still must ask whether the incumbents have produced sufficient evidence that defensive tactics benefit target company shareholders to justify their negative effect on shareholder voting rights.

\section{Incumbents' Burden to Justify Using Rights Plans (and Other Defensive Tactics) in Proxy Contests}

Once a court has found that a proxy contest poses a legitimate threat to a company's shareholders, and that the proposed defensive tactic has an adverse impact on a dissident's proxy solicitation campaign, it still needs to decide if the proposed defense makes the target company's shareholders better off. Under the existing judicial tests, the incumbents have the burden of producing evidence to show that they acted in the shareholders' best interests in deploying defensive tactics. However, once the incumbents produce evidence that, after a reasonable investigation, they acted in good faith in what they believed to be shareholders' or the corporation's best interests, the burden of persuasion shifts back to the dissident. ${ }^{247}$

Incumbents should retain the burden of persuading the court that any proposed defensive tactic benefits the target company's shareholders. Shareholders' right to control their investments through the exercise of the franchise is a critical part of the corporate contract in a change of control situation. ${ }^{248}$ This is particularly true today with the demise of the tender offer and the increased use of indexing by large institutional shareholders. If the courts want to prevent the complete separation of ownership and control, they cannot permit incumbents to block or impede the shareholders' exercise of their franchise in change of control situations.

246. Id. at *31. The use of experts can be costly. In a recent case involving complex computer software copyright issues, the court paid its expert $\$ 4500$ per day. Moses, Wall St. J. at B8 (cited in note 243 ).

247. See Part II.C.1. for further discussion. The Delaware Supreme Court's decision in Stroud $v$. Grace may require incumbents to offer better justifications for using defensive tactics that adversely impact the shareholder franchise in a contest for control. See Stroud, 606 A.2d at 92 n.3 (saying that "[a] board's unilateral decision to adopt a defensive measure touching 'upon issues of control' that purposefully disenfranchises its shareholders is strongly suspect under Unocal, and cannot be sustained without a "compelling justification' "). It is too early to tell if the court intended to impose a heavier burden on incumbents to justify defensive tactics in proxy contests or if the requirement that the board be acting to "purposefully disenfranchise" stockholders will be so difficult to prove that this standard is never invoked.

248. See Part III.B. for further discussion of this point. 
Moreover, many of the theoretical arguments in favor of these defensive tactics are weak. The claim that victorious small shareholders are hikely to reduce the value of target corporations ignores the importance of informed voting patterns by large institutional shareholders. Similarly, the increased concentration of share-ownership has ameliorated the information problem justification for defensive tactics offered by Bebchuk and Kahan. ${ }^{249}$ Furthermore, stockholders appear to accrue significant benefits from proxy contests. ${ }^{250}$

The only arguments that might justify the use of defensive tactics in proxy contests and joint offers are those advanced in favor of blocking tender offers. For example, a court might permit incumbents to use a Rights Plan to delay a joint offer so that the board can solicit other alternative transactions for shareholders to create an auction for the company. Management could rationalize this tactic as a response to a threat of substantive coercion if it believed that it could do a better job of selling the company or restructuring it than could the dissidents.

In a pure proxy contest, management could justify those provisions of Rights Plans that have only a minor negative impact on a dissident's campaign as necessary to stop the threats created by tender offers, much as the Moran court found. However, the courts should adopt a per se rule against those provisions of Rights Plans that are designed solely to impede proxy contests. Thus, for example, a court should automatically strike down any provisions that would limit dissident shareholders' ability to accept revocable proxies. ${ }^{251}$

Management cannot justify terms in Rights Plans that the drafters designed primarily to stop proxy contests as reasonable responses to any threat. Courts should scrutinize preclusive defensive tactics particularly closely because of the danger of entrenching management permanently in office. A per se rule invalidating these restrictions would stop incumbents from using frivolous litigation to tie up dissidents and to delay their proxy campaigns. It also would strengthen shareholders' ability to exercise their rights to remove unwanted managers.

In practice, how would the courts apply these rules to Rights Plans' application in proxy contests? Suppose that in a joint offer, the target company's Rights Plan's definition of beneficial ownership was being used to block a dissident shareholder group's attempts to communicate with other shareholders. The incumbents might state that these restrictions were needed to prevent shareholders from mistakenly accepting

249. See Part III.C.1. for further discussion of this point.

250. See notes 166-76 and accompanying text for further discussion of this point.

251. See, for example, Sutton, 1991 Del. Ch. LEXIS 85 at $* 2-3$. 
the dissidents' tender offer when existing management could raise the value of the company above the price offered by the dissidents.

The courts should demand that the incumbents prove that the Rights Plan's restrictions would have hitle or no impact on the dissident group's election campaign. If the incumbents can produce statistical proof, or persuasive expert witness testimony, to show that this is true, the likelihood that their actions are aimed at entrenching themselves in office seems remote. Even if they are trying to entrench themselves, this evidence would show that the Rights Plan will not help them to do so.

If the Rights Plan's terms had a significant negative effect on a dissident group's ability to make its case to the shareholders, and were not a necessary part of its tender offer defenses, the court would invalidate the infringing provisions without further investigation. This seems particularly true when the defensive tactic interferes with a shareholder group's ability to communicate with other shareholders or with other important voting rights, such as the right to nominate candidates, or the right to communicate with other shareholders. ${ }^{252}$ Here, restricting shareholders' ability to communicate with each other seems unlikely to benefit them. A court should strike down this type of application of a Rights Plan. ${ }^{253}$

If the suspect provisions of the Rights Plan were central to the Rights Plan's use as a tender offer defense, then incumbent management would still need to show that these terms directly benefited the target company's shareholders. The likelihood that incumbents are acting to entrench themselves now appears quite high. Only when management can make a strong case that the Rights Plan will directly improve

252. In this regard, the courts might want to determine the significance of the voting rights at issue with an expanded version of Chancellor Allen's distinction between a constitutional right to vote and other voting rights in Lennane v. ASK Computer Systems, Inc., No. 11744, 1990 Del. Ch. LEXIS 164 (Oct. 11, 1990). In Lennane, the chancellor wrote that the right to vote is constitutional when "the corporation law statute, the certificate of the corporation or the company's bylaws creates a right to vote on a matter." Id. These rights are entitled to great deference by the directors. Id.

The courts would need to expand this distinction in the context of proxy contests to take into account the importance of the voting rights to a dissident's chances of winning a proxy contest. For example, the right to nominate directors, the right to timely access to a stockholders' list, and the right to get proposals on the meeting agenda, all have a major impact on a dissident's chances of winning a contest. See, for example, Gordon, $60 \mathrm{U}$. Cin. L. Rev. at 361-63 (cited in note 10) (discussing the importance of agenda control in determining the outcome of voting process). The courts should carefully scrutinize defensive tactics that infringe on any of these crucial voting rights.

253. See Henley Group, Inc. v. Santa Fe Southern Pacific Corp., C.A. No. 9569 (Del. Ch. Mar. 11, 1988). 
the target company shareholders' welfare, such as through a sale to a third party, should the courts approve the use of a Rights Plan.

As this example shows, this test would give the courts a flexible and fact-sensitive method of determining when to permit Rights Plans' use in proxy contests. Contestants would quickly litigate and settle the validity of the more common uses of Rights Plans. Courts could analyze new wrinkles in the use of Rights Plans (and other defensive tactics) in new and unexpected situations more readily.

\section{Conclusion}

Incumbent management has long enjoyed broad discretion in its use of Rights Plans in proxy contests and joint offers. Legal scholars have accepted the justifications for permitting incumbents such latitude with little comment. The courts also have largely deferred to management's decisions about how they use Rights Plans against dissident shareholder groups.

The analysis presented here argues that courts sbould apply stricter standards. A more stringent balancing test that forces incumbents to justify the use of Rights Plans by explaining how the Rights Plan prevents a specific harm to their shareholders would better protect shareholders from abusive defensive tactics. For any particular defensive tactic, a court must question the explanations offered by incumbents and place the burden of persuasion on management to show that they are acting in shareholders' best interest.

The courts should invalidate without further judicial inquiry those provisions of Rights Plans that are directed primarily toward impeding dissidents' proxy campaigns. Courts should permit Rights Plans in proxy contests only when the incumbents can show that the contests are necessary parts of the company's tender offer defense, that their impact on the outcome of a proxy contest will be minimal, and that direct benefits to the target company shareholders justify their adverse effects on dissidents' election campaigns.

To determine the impact of particular defensive measures on the outcome of proxy contests, the courts should demand that the parties submit statistical evidence and expert testimony about the effects of Rights Plans on the outcome of the proxy contest. Only after examining the impact of the defensive tactic on the outcome of the proxy contests, and finding it justified by the benefit to the target company's shareholders, should a court approve any use of Rights Plans in proxy contests. When the incumbents fail to carry this burden, then the court should strike down these defenses and permit shareholders to exercise their vote in corporate elections freely and without restraint. 